\title{
Suspended sediment and dissolved load budgets of two Amazonian rivers from the Guiana shield: Maroni river at Langa Tabiki and Oyapock riverat Saut Maripa (French Guiana).
}

\author{
Francis SONDAG ${ }^{1}$, JEAN LOUP GUYOT ${ }^{2}$, JEAN SÉbaSTiEn MOQUET ${ }^{3}$, Alain \\ LARAQUE ${ }^{4}$, GEORges ADELE ${ }^{4}$, GÉRARd COCHONNEAU ${ }^{2}$, JEAN ClAUde \\ DOUdOU $^{5}$, Christelle LAgane $^{1}$, \& Philippe VAUCHEL ${ }^{3}$
}

\author{
${ }^{1}$ IRD-LMTG (Université de Toulouse, CNRS, IRD, OMP), 14 avenue Edouard Belin, \\ Toulouse, France, francis.sondag@ird.fr \\ 2 IRD-LMTG (Université de Toulouse, CNRS, IRD, OMP), CP 7091, Lago Sul, \\ 71619-970 Brasilia, DF, Brazil \\ ${ }^{3}$ IRD-LMTG (Université de Toulouse, CNRS, IRD, OMP), Casilla 18-1209, \\ Lima 18, Peru \\ ${ }^{4}$ IRD-OBHI, BP 8006, 97259 Fort-de-France cedex France \\ ${ }^{5}$ IRD-OBHI, BP 165, 97323 Cayenne cedex, France
}

\begin{abstract}
This work presents the data collected within the framework of an Observatory of research in Environment on the Amazonian basin - the ORE HYBAM. It relates to the dissolved and solid loads of the two main rivers of French Guiana, the Maroni and Oyapock rivers, running on the Guiana shield and draining respectively 64230 and 24 $630 \mathrm{~km}^{2}$. The low coefficient of variation of the average annual flows of the two rivers indicates an inter-annual hydrological stability probably related to the immediate vicinity of the Atlantic Ocean. The sedimentary load is mainly composed of quartz and kaolinite. The total suspended solid concentrations are among the world's lowest values; they range from 1 to $130 \mathrm{mg} \mathrm{l}^{-1}$ during the hydrological cycle, with averages of 22 and $12 \mathrm{mg} \mathrm{l}^{-1}$, for the Maroni and Oyapock rivers respectively. The seasonal variability of these values is significantly higher than that of hydrologic flows, but without simple relationship with the discharge. Water chemical composition of the two rivers indicates a very weak mineralization, very similar to that found in the Amazonian rivers running on the Brazilian and Guianese shields and in the Congo River and its tributaries in the Central African Shield. Seasonal variations are observed in both basins; they correspond to higher concentrations during low water stage (from October to February) and to more diluted water during the flood, from April to July. A signature enriched in $\mathrm{Cl}^{-}$is present at the Saut Maripa station on the Oyapock River indicating a more marked influence of the trade winds in this basin. The computation of atmospheric contributions to ions budget indicated a weak contribution for $\mathrm{Ca}^{2+}$ and $\mathrm{Mg}^{2+}$, which originates mainly from water-rock interactions in both stations, while more than half of $\mathrm{Na}^{+}$is derived from atmospheric inputs.
\end{abstract}

\section{Key words.}

Hydrology, Suspended Sediment, Geochemistry, French Guiana, Amazon Region 


\section{INTRODUCTION}

The yield of suspended and dissolved materials is of fundamental interest for the computation of weathering and erosion rates. As runoff varies seasonally in tropical watersheds, regular sampling over some annual hydrological cycles should provide the best basis for estimating element budgets.

In French Guiana, the existing hydrological studies, conducted primarily by IRD (ex ORSTOM), focused on the recognition of potential sites for hydropower dam (Roche, 1978a; Fritsch, 1982, 1985), on the study of estuarine systems (Berthois \& Hoorelbeck, 1964; Roche et al., 1974; Lointier, 1990; Vauchel, 1998), and on the effect of the rainforest clearing on soil erosion (Roche, 1978b, 1982; Fritsch , 1983, 1987, 1992, Fritsch \& Sarrailh, 1986; Bariac et al., 1996). To date, major rivers in the region have been only preliminary studied (Hiez, 1955; Hiez \& Dubreuil, 1963) while the data on the dissolved and particulate flows essential for assessment erosion and weathering rates of these major tropical basins remains fragmented (Humbel, 1989; Lointier \& Roche, 1989; Lointier 1995). A recent report of Monfort and Ruf (2005) assessed the main characteristics of the hydrological regimes of the rivers of French Guiana.

This paper reports the results of four years of a monthly survey in two forested tropical watersheds of French Guiana. The survey was performed in the frame of the Environment Research Observatory HYBAM (Geodynamical, hydrological and biogeochemical controls of erosion/alteration and material transport in the Amazon basin, http://www.ore-hybam.org). This observatory comprises 16 gauging and sampling stations distributed along the Amazon Basin and in the Andean piedmont; its main objective is the acquisition of long term data series to evaluate the climatic and human impacts. The two stations presented here are situated in French Guiana. One is located on the Maroni River, at Langa Tabiki, and the other one is situated on the Oyapock River at Saut Maripa. Both rivers correspond to the boundaries of French Guiana with a neighbouring country: in the West, the Maroni River follows the limit of Suriname and, in the East, the Oyapock River determines the border with Brazil. Sampling started in April, 2004 in both sites and was performed monthly.

\section{STUDIED AREA}

The studied area corresponds to the drainage basins of the two main rivers of French Guiana: the Maroni and the Oyapock rivers (Figure 1 and Table 1).

The Maroni River is the largest river of this region. This river comes from the western Tumuc Humac hills located in Suriname, where it is locally named Itany River. Downstream the confluence with Inini River, its name changes to Lawa River, and finally downstream Tapanahony River confluence, it becomes the Maroni River. At the Langa Tabiki gauging station (LT), the Maroni river drains a $64230 \mathrm{~km}^{2}$ area, 43\% located in French Guiana and 57\% in Suriname (Hiez \& Dubreuil, 1963).

The Oyapock River delimits the French Guiana border with Brazil. The river comes from the eastern Tumuc Humac hills, and flows downstream to the NE, despite more than 100 "sauts" (small waterfalls). With its main tributary (the Camopi River), the Oyapock River at the Saut Maripa gauging station (SM), drains a $24630 \mathrm{~km}^{2}$ area, 49\% located in French Guiana and 51\% in Brazil (Hiez \& Dubreuil, 1963). 
The Guiana region can be divided into three distinct morphological units (Barret, 2002):

i. the low-land zone corresponds to the littoral plain with an altitude lower than $30 \mathrm{~m}$ a.m.s.l.; its extension varies from 5 to $40 \mathrm{~km}$ wide,

ii. the "Central Massif" extends over $\pm 100 \mathrm{~km}$ and corresponds to the Green Belt domain of the Guiana Shield. It has a general WNW/ESE orientation and comprises deeply eroded massifs with an altitude ranging from 400 to 850 m a.m.s.l.,

iii. the southern peneplain consists of convex hills less than $250 \mathrm{~m}$ high. Many "inselbergs" are present in this area, contrasting with the monotone landscape of the low hills.

The studied area is situated in the northern and eastern parts of the Guiana Shield, which extends over the north of the Brazilian Amazon Basin, the West of Colombia and Venezuela and covers the French Guiana, the Surinam and the Guiana. In the Northeast of Brazil and south of French Guiana, it consists of igneous rocks (granite, gabbro, diorite) of Paleo-Proterozoic ages. These rocks are locally metamorphized and amphibolitized. The centre and north of French Guiana is composed of greenstone belts oceanic rocks and has been affected by the Trans-Amazonian tectonic and metamorphic event (Gibbs \& Barron, 1993; Gibbs et al., 1986)

Intense weathering of the bedrocks since the Cretaceous in this very stable area has induced the development of a thick layer of residual alterite masking the substratum (Edmond et al., 1995 ; Negrel \& Lachassagne, 2000). However, a recent (Quaternary) uplift is observed, probably associated with the peripheral bulge engendered by sediment loads of the Amazon fan (Driscoll \& Karner, 1994). It could explain the drainage of unweathered material in some parts of the basins.

The climate of this region is governed by the displacements of the Intertropical Convergence Zone (ITCZ) resulting from the convergence of the Trade Winds blowing from the high-pressure areas in the subtropical latitudes towards the lowpressure areas around the equator. Four seasons can be distinguished (Groussin, 2002). From mid-November to mid-February, the ITCZ moves southwards and passes over the land, giving rise to a little rain season. In March, the ITCZ reaches its maximum southern position (between $1^{\circ} \mathrm{S}$ and $2^{\circ} \mathrm{N}$ ); this period corresponds to a diminution of average rainfall. From April on, the ITCZ moves slowly northward and consequently an intense rainy season develops until July. From August to the end of October, the ITCZ is in a more northern position and a dry season occurs. As a consequence of the direct relationship between rainfall and the displacement of the ITCZ, a clear east-west trend appears in average total annual rainfall: it ranges from $3500-4000 \mathrm{~mm}$ in the east to $1700-2000 \mathrm{~mm}$ in the west. The mean annual rainfall for Langa Tabiki and Saut Maripa drainage basins is respectively $2520 \mathrm{~mm}$ and $2680 \mathrm{~mm}$. The mean annual temperature is $26.5^{\circ} \mathrm{C}$ and is relatively constant all along the year (Hiez \& Dubreuil, 1963).

The studied area is mainly covered by a dense tropical forest with high ecological biodiversity. Along the coast, some areas of mangrove and swamp exist.

\section{MATERIAL AND METHODS}

The present study concerns hydrology, suspended sediment and dissolved yields of the Maroni and Oyapock rivers, French Guiana. Suspended sediment and geochemical 
data comes from samples collected in these two rivers between April, 2004 and January, 2008, in the frame of the ORE HYBAM observatory.

The Langa Tabiki gauging station on the Maroni River was installed by IRD (exORSTOM) in 1952, and the Saut Maripa station on the Oyapock River in 1953. These two gauging stations are not influenced by oceanic tidal cycles (Hiez, 1955; Hiez \& Dubreuil, 1963). In the past, water levels were monitored two times a day, and today, every half hour by limnimetric "Cloe" type sensors. The Langa Tabiki and Saut Maripa gauging stations present good and stable rating curves, calibrated on the basis of respectively 77 and 80 discharge measurements from 1953 to 2001 at each station. Daily discharges have been calculated using HYDRACCESS software (available by free download at http://www.mpl.ird.fr/hybam/outils/hydraccess.htm).

The limit and extent of the basins were obtained by extracting the topographic limits river basins from Shuttle Radar Topography Mission (SRTM) map.

The total suspended solid material (TSS) was collected monthly in the center of the river, and then measured by filtration of 1 liter of water on $0.45 \mu \mathrm{m}$ cellulose acetate filters. After weighting, the suspended sediments were separated from the filter by agitation in an ultrasonic bath. They were transferred in Teflon ${ }^{\circledR}$ containers and subjected to a total dissolution procedure using hot $\mathrm{HF}-\mathrm{HNO}_{3}$, after a short preliminary $\mathrm{H}_{2} \mathrm{O}_{2}$ digestion eliminating organic material. Due to the nature of the filters used (nitrocellulose), no POC determination was undertaken. The TSS yield computation is discharge-weighted, using mean monthly discharge and TSS values of the month.

The samples for geochemical analysis of dissolved material were collected monthly in acid-washed HD polyethylen containers, near the water surface, in the middle of the river by IRD hydrologists of Cayenne. They were filtered in the IRD laboratory at Cayenne through $0.22 \mu \mathrm{m}$ DURAPORE ${ }^{\circledR}$ filters. Samples were stored in acidwashed HD polyethylen bottles. The samples for anions determinations were not acidified while those for major cations and trace element determination were acidified with ultrapure $\mathrm{HNO}_{3}$. The samples for dissolved organic carbon (DOC) determination were stored in glass bottles previously burned in an oven at $450^{\circ} \mathrm{C}$ during two hours; they were acidified with ultrapure $\mathrm{H}_{3} \mathrm{PO}_{4}$.

The major anions $\left(\mathrm{F}, \mathrm{Cl}, \mathrm{NO}_{3}, \mathrm{PO}_{4}, \mathrm{SO}_{4}\right)$ were determined using ion chromatography and $\mathrm{Ca}, \mathrm{Mg}, \mathrm{Na}, \mathrm{K}, \mathrm{Fe}, \mathrm{Si}, \mathrm{Al}, \mathrm{Mn}, \mathrm{Ti}$ and $\mathrm{P}$ were determined by ICP-OES. For DOC analysis, a high temperature catalytic oxidation (HTCO) method was used. The TDS and elemental yields computation are also discharge-weighted.

The analytical precision, evaluated using repeated standard reference materials analysis, is generally better than $10 \%$ while reproducibility was determined using replicate sample analysis and is better than $5 \%$.

\section{RESULTS AND DISCUSSION}

\section{Hydrology}

For the whole dataset, from 1951 to 2007 (Table 1 and Figure 2), annual mean discharge data for the Maroni River is $1700 \mathrm{~m}^{3} \mathrm{~s}^{-1}$, with a minimum of $820 \mathrm{~m}^{3} \mathrm{~s}^{-1}$ (1964) and a maximum of $2640 \mathrm{~m}^{3} \mathrm{~s}^{-1}$ (1971). For this river, the variation coefficient (or RSD: standard deviation / mean value) is 0.28. At Saut Maripa, the Oyapock River 
presents a mean annual discharge of $830 \mathrm{~m}^{3} \mathrm{~s}^{-1}$, a minimum of $360 \mathrm{~m}^{3} \mathrm{~s}^{-1}(1983)$, and a maximum of $1440 \mathrm{~m}^{3} \mathrm{~s}^{-1}$ (1989). The variation coefficient is 0.24 , indicating a relative stability of the inter-annual hydrological regime, probably due to the proximity of the Atlantic Ocean. The extreme values present a good similitude with the Amazon River discharge at the Óbidos gauging station in Brazil, where large flooding were observed in 1974-1976, 1989 and 1999, and low water in 1964, 1980, 1983, 1992 and 1998 (Callède et al., 2004).

Mean discharge observed during the 2004-2007 period (sampling period) is $1840 \mathrm{~m}^{3} \mathrm{~s}^{-1}$ and $790 \mathrm{~m}^{3} \mathrm{~s}^{-1}$ respectively for Langa Tabiki and Saut Maripa (Table 2), these values are very close to the mean value of the long time observation period (Table 1). The seasonal variability of the discharge is similar for the two stations (Figures $3 \mathrm{a}$ and $\mathrm{b}$ ), with the beginning of the hydrological cycle in November, a first flooding period from December-January to February-March, and a second larger flood from April to July-August, as observed by Hiez and Dubreuil (1963).

\section{Suspended Sediment load}

On the basis of the 47 samples collected monthly at each of the two stations, an initial characterization of sedimentary flow has been achieved. The Total Suspended Solid (TSS) concentrations range from 1 to $130 \mathrm{mg} \mathrm{l}^{-1}$ during the hydrological cycle, with discharge - weighted averages of $21.9 \pm 1.6$ and $12.1 \pm 1.2 \mathrm{mg} \mathrm{l}^{-1}$, for the Maroni and Oyapock rivers respectively (Table 2). This last value is very similar to the result of Lointier (1995) at Saut Maripa who obtained a mean value of $12.7 \pm 3.4 \mathrm{mg} \mathrm{l}^{-1}$, in his one year survey with sampling every two days. It should be noted that part of the TSS is organic but due to sampling conditions the particulate organic carbon was not determined. The seasonal variability of these values is significantly higher than that of hydrologic flows (RSD from 0.89 for LT and 1.17 for SM), but without simple relationship with the flow (Figure 4a). The solid flow obtained show a similar variability, with peaks of sediment flows quite well related with the hydrological maxima (Figures 3a and b). These flows, with interannual average value of $3750 \mathrm{t}$ day $^{-1}$ at Langa Tabiki and $940 \mathrm{tday}^{-1}$ at Saut Maripa correspond to very low physical erosion rates, which are respectively 21 and $14 \mathrm{t} \mathrm{km}^{-2}$ year ${ }^{-1}$ for the Oyapock and the Maroni. These values are comparable to those observed on the rivers of Bolivia (Guyot et al., 1996) and of Brazil over the Brazilian and Guiana shields (Filizola, 2003) under tropical and equatorial climates. This is also observed in the Congo basin which is also located on an old shield and presents similar climatic conditions (Laraque et al., 1998, Laraque et al,2009).

Mineralogical and chemical composition. X-ray diffraction was performed on some samples and indicated the presence of kaolinite as the main mineralogical component with low (les than 5\%) quartz and amorphous phases. As observed on the whole Amazonian basin, kaolinite seems to be the characteristic clay mineral of river sediments issued from Brazilian and Guianese shields (Guyot et al., 2007). No noticeable variations were encountered during the hydrological cycles. The Table 3 presents the mean, minimum and maximum values of major elements in the suspended sediments from both stations. Due to analytical procedure, $\mathrm{SiO}_{2}$ content was not determined, and the dilution effect of quartz was not evaluated, since, as stated before, quartz concentrations are generally low. Ti and $\mathrm{P}$ where generally below detection limit, probably because of the low amount of material present on the filter and of the final dilution of sample before ICP-OES determination. The 
sediments are mainly composed of $\mathrm{Al}$ and $\mathrm{Fe}$, which correspond to a classical weathering product in tropical areas. No obvious differences are apparent between the stations, with the exception of $\mathrm{K}$ which presents a threefold increase at Langa Tabiki (mean: $1.23 \%$ ) with respect to Saut Maripa $(0.48 \%)$.

By multiplying the relative concentrations (\%) of the various elements by the sediment yield (Table 2), the flow of each element of the particulate phase is obtained (Table 3). The main exported element, apart from $\mathrm{SiO}_{2}$ not determined, is the $\mathrm{Al}$ (507 $\mathrm{t} \mathrm{day}^{-1}$ at LT and $139 \mathrm{t} \mathrm{day}^{-1}$ at SM), followed by Fe (234 $\mathrm{t} \mathrm{day}^{-1}$ to LT and $68 \mathrm{t} \mathrm{day}^{-1}$ to SM ).

\section{Dissolved load}

The whole geochemical data base of the survey is available on the project website (http://www.ore-hybam.org). The Table 4 presents the mean values of the major elements and dissolved organic carbon (DOC) concentrations, the $\mathrm{pH}$, and the conductivity during the four years of the survey for both rivers. This table also gives the minimum and maximum encountered values.

Major elements. The geochemistry of the dissolved material from the rivers of Guiana has been established on the basis of the 53 samples collected monthly since April, 2004.

Both rivers are characterized by dilute waters as indicated by a mean total cationic charge $\left(\Sigma^{+}\right)$of $\sim 200 \mu \mathrm{eq} / \mathrm{L}$ (Table 4 ). They present slightly acid to near neutral $\mathrm{pH}$, low conductivity values and molar $\mathrm{Ca}^{2+} / \mathrm{Na}^{+}$ratio $<1$. Although very diluted with regards to the Amazon river and its main tributaries, the Solimões and the Madeira rivers (Table 5), these waters are however more concentrated than the black water rivers found in the Amazon basin, such as the Rio Negro river (Gaillardet al.,1997), or the Caroni River (Edmond et al.,1995), in the Orinoco basin. Their total cationic and anionic charges are more similar to those found in the Congo basin (Dupré et al, 1996) but they differ by their lower dissolved silica content.

For SM, our values are very close to those found by Lointier (1995) who reported a mean conductivity of $20.9 \pm 2.3 \mu \mathrm{S} \mathrm{cm}^{-1}$, mean value of $0.73 \pm 0.10 \mathrm{mg} \mathrm{l}^{-1}$ for $\mathrm{Ca}^{2+}$, $2.47 \pm 0.30 \mathrm{mg} \mathrm{l}^{-1}$ for $\mathrm{Cl}^{-}$and $4.74 \pm 0.72 \mathrm{mg} \mathrm{l}^{-1}$ for $\mathrm{Si}$. As already observed for the suspended load, it appears thus that the monthly time scale used in our study leads to the acquisition of results very similar to those acquired with a much higher frequency (every two days in the case of the work of Lointier).

The mean normalized inorganic charge balance ( $\left.\mathrm{NICB}=\Sigma^{+}-\Sigma^{-}\right) / \Sigma^{-}$) is very low (SM $=4 \%, \mathrm{LT}=5 \%)$. However, it has a large range of variation along the hydrological cycle (SM: from +44 to $-24 \%$, LT: from +44 to $-19 \%$ ). The Figure 5 indicates that these variations are clearly linked to the DOC concentration, as the samples with high NICB value present high DOC content and conversely. This confirms thus the observations reported by numerous other authors in tropical river basins like the Congo Basin (Dupré et al., 1996; Probst et al., 1992), the Amazon Basin (Gaillardet et al., 1997) and the Orinoco Basin (Edmond et al., 1995), who assumed that the imbalance could be linked to the dissociation of organic acids producing $\mathrm{H}^{+}$ions and organic anions. The dominant anionic species is $\mathrm{HCO}_{3}^{-}$followed by $\mathrm{Cl}^{-}$. The Maroni River has a $10 \%$ higher TDS value than the Oyapock River.

At Langa Tabiki, the major ions are generally inter-correlated, except $\mathrm{NO}_{3}{ }^{-}$which is not interconnected with other ions (Table 6a). At Saut Maripa (Table 6b), $\mathrm{Ca}^{2+}$ is 
weakly correlated only with $\mathrm{Na}^{+}$and $\mathrm{HCO}_{3}{ }^{-}$while other cations are well intercorrelated, and correlated with $\mathrm{Cl}^{-}$. The very significant correlation between $\mathrm{Na}^{+}, \mathrm{K}^{+}$ and $\mathrm{Cl}^{-}$should be emphasized and will be discussed further.

In terms of dissolved material discharge, the Maroni River has a significant higher exportation value with more than $3910 \mathrm{t} \mathrm{day}^{-1}$ compared to $1430 \mathrm{t} \mathrm{day}^{-1}$ in the Oyapock River (Table 2). As the drainage area at LT is much greater $\left(64230 \mathrm{~km}^{2}\right)$ than at SM (24 $\left.630 \mathrm{~km}^{2}\right)$, the calculated weathering rate is very low, nevertheless similar for both stations (22 and $21 \mathrm{t} \mathrm{km}^{-2}$ year $^{-1}$ respectively). Considering physical erosion rate and weathering rate, total denudation rate of these two equatorial drainage basins range from 44 (LT) to 35 (SM) $\mathrm{t} \mathrm{km}^{-2}$ year $^{-1}$. On the Maroni River, TDS and TSS yields are equivalent, whereas on the Oyapock River TDS represent $60 \%$ of the total exportation yield. Looking at the elemental composition of the total exported material, $\mathrm{Al}$ and $\mathrm{Fe}$ are the main components of the particulate phase while $\mathrm{Na}^{+}$and $\mathrm{Ca}^{2+}$ dominate in the dissolved load (Table 7). The Soluble Transport Index (STI = $\mathrm{QD} /(\mathrm{QD}+\mathrm{QS})$, Martin and Meybeck, 1979) is very high for the major cations, even if their absolute concentrations are relatively low.

Seasonal variability. All the major elements show a regular seasonal pattern (Fig. 6): the higher concentrations are related to the low water stage, from October to February, while more dilute waters occur during the flood from April to July. Figure $4 \mathrm{~b}$ presents a slight negative relationship between discharge and TDS load for both gauging stations. Monthly discharge and TDS yield variability are very similar for the two rivers (Figure $3 \mathrm{a}$ and $\mathrm{b}$ ) but it should be noted that the TDS are higher than TSS nearly $95 \%$ of time for the Oyapock river whereas this occurs only nearly $50 \%$ for the Maroni river; this is probably due to an oceanic influence at SM (see below).

On a ternary cation $\left(\mathrm{Ca}^{2+}, \mathrm{Mg}^{2+}, \mathrm{Na}^{+}+\mathrm{K}^{+}\right)$diagram (Fig. 7), all the samples fall on a linear trend close to the $\left(\mathrm{Na}^{+}+\mathrm{K}^{+}\right)$apex; a slight displacement towards $\mathrm{Ca}^{2+}$ appears for some samples from both rivers. This pattern was found also by Edmond et al. (1995). As the computed estimated chemical composition of average igneous rocks falls in the same envelope, they concluded that, in first approximation, the weathering processes go to completion without retention of the cations in secondary phases. This should thus also be the case for the rivers of French Guiana.

The ternary anion $\left(\mathrm{Si}, \mathrm{HCO}_{3}^{-}, \mathrm{Cl}+2 \mathrm{SO}_{4}{ }^{2-}\right)$ diagram (Fig. 8) shows that the LT samples have a more alkaline composition than the SM samples which are richer in $\mathrm{Cl}^{-}$(mean value: $\mathrm{SM}=64.3 \mu \mathrm{mol} \mathrm{L}{ }^{-1}, \mathrm{LT}=51.9 \mu \mathrm{mol} \mathrm{L}^{-1}$ ). This higher $\mathrm{Cl}^{-}$content probably reflects a greater contribution of sea-salt aerosol conveyed by the dominant winds blowing from east to west. On a Na-Cl diagram (Fig. 9), the SM samples are closer to the sea-salt line than the LT samples; their mean $\mathrm{Na}: \mathrm{Cl}$ ratio is also lower (1.34 and 1.76 respectively). This ratio is however far above the value of sea-salt (0.86) indicating that $\mathrm{Na}$ has also a continental source. As can be seen on figure 10 , the Cl:Na ratio at SM is generally well correlated with discharge, which is not the case at LT. This pattern is thus clearly related to the greater influence of the trade winds bringing the rain to that station. 


\section{Atmospheric contribution}

As atmospheric inputs can contribute significantly to the chemical composition of both rivers, we try to evaluate this impact on the dissolved load budget. The composition of the rain water has mostly an oceanic origin but can also be influenced by other sources. $\mathrm{Na}^{+}$and $\mathrm{Ca}^{2+}$ concentration can be influenced by continental inputs, the $\mathrm{NO}_{3}^{-}$have a mainly continental influence and $\mathrm{K}^{+}$concentration can be influenced by the vegetation (Gaillardet et al.,1997; Negrel et al.,1997; Negrel and Lachassagne, 2000). According to Meybeck (1983), when $\mathrm{Cl}^{-}$in river is exclusively originating from rainfall, the correction of atmospheric inputs can be estimated for any element $\mathrm{X}$ referring to the $\mathrm{Cl}^{-}$concentration in the stream multiplied by the $\mathrm{X} / \mathrm{Cl}$ ratios in the rainwater. In rivers, the main sources of $\mathrm{Cl}^{-}$are the rain contribution, the halite dissolution (evaporitic rocks), the anthropogenic inputs (Meybeck, 1983; Stallard and Edmond, 1981) and the leaching of the canopy (Millet et al., 1999). In the studied area, no evaporitic rocks are present (Edmond, 1995). The vegetation impact is difficult to quantify (Chave, 2005), and we will consider this contribution as negligible compared to the great influence of sea proximity to the basins. The human impact has also been considered as negligible as the population density in both basins in less than 1 people per $\mathrm{km}^{2}$ (Guillemet, 2002). All the $\mathrm{Cl}^{-}$exported by the Maroni and the Oyapock rivers has thus been supposed to come from atmospheric inputs.

As showed by Stallard and Edmond (1981), the $\mathrm{Cl}^{-}$concentration in the rain decreases with the distance from the ocean. The greater influence of the Atlantic inputs on the Opayock basin than on the Maroni basin induces higher $\mathrm{Cl}^{-}$ concentration at SM (mean value : $2.28 \pm 0.16 \mathrm{mgL}^{-1}$, Table 4) that at LT (mean value : $1.84 \pm 0, .4 \mathrm{mgL}^{-1}$ ). Without fractionation of the rain composition, the $\mathrm{X} / \mathrm{Cl}$ ratio is constant in space and during time. Negrel et al. (1997) studied the time variability of rain composition in Cayenne (French Guiana) and Negrel and Lachassagne (2000) studied the space variability of rain composition on the Maroni basin. The $\mathrm{X} / \mathrm{Cl}$ measured during those studies confirmed a spatial and time variability. The time variability of $\mathrm{X} / \mathrm{Cl}$ ratio at Cayenne can be explained by the variation of the origin of air masses during the year while the spatial variability can be explained by the variation of continental inputs on rain water. To integrate these variabilities, we decided to calculate an average of X/Cl rain from the Negrel et al. (1997) and Negrel et Lachassagne (2000) data. On the Cayenne data, we excluded the September data because of the high influence of continental dust contamination on the sample reported by the authors. The standard deviation calculated on those values was used to evaluate the accuracy of the data. The data of table 8 were used to calculate:

$$
\begin{aligned}
& \text { Xrain }=\text { X/Clrain } * \text { Clriv } \\
& X \%=\text { Xrain } / \text { Xriv }
\end{aligned}
$$

where :Xrain is the contribution of the atmospheric inputs to the element budget;

$\mathrm{X} / \mathrm{Cl}$ rain is the ratio $\mathrm{X} / \mathrm{Cl}$ of the rain;

Clriv is the $\mathrm{Cl}^{-}$concentration of the river;

$\mathrm{X} \%$ is the relative atmospheric contribution to the element $\mathrm{X}$.

The equations (1) and (2) were applied on each monthly value. The table 9 presents the average of the relative atmospheric contribution, the RSD calculated on the monthly relative atmospheric contribution and the variability of the $\mathrm{X} / \mathrm{Cl}$ rain applied on the monthly values.

Due to weak contribution from rain inputs, the $\mathrm{Ca}^{2+}$ and $\mathrm{Mg}^{2+}$ mean values are $15 \pm 3 \%$ and $15 \pm 5 \%$, respectively, on the Maroni river, and $27 \pm 6 \%$ and $23 \pm 4 \%$ on the Opayock river. The source of those cations is thus mainly the water-rock 
interaction. Conversely, a great rainfall contribution is observed for $\mathrm{Na}^{+}(48 \pm 6 \%$ and $63 \pm 8 \%$ for the Maroni and for the Opayock respectively). It should be noted that Maroni river results are consistent with the conclusions of Negrel and Lachassagne (2000) who obtained similar proportions for $\mathrm{Ca}^{2+}$ and $\mathrm{Mg}^{2+}$ rain inputs (average $10-$ $14 \% \pm 1.3-3.4 \%)$ and for $\mathrm{Na}(48.2 \pm 3.9 \%)$. Similar proportions were also recorded in the Congo Basin (Negrel et al, 1993). In the Amazon Basin, Gaillardet et al., 1997, observed similar proportion for $\mathrm{Na}^{+}$and $\mathrm{Mg}^{2+}$, but a lower contribution for $\mathrm{Ca}^{2+}$. For $\mathrm{K}^{+}, \mathrm{NO}_{3}^{-}$and $\mathrm{SO}_{4}{ }^{2-}$, it is difficult to evaluate the atmospheric contribution because of the great $\mathrm{X} / \mathrm{Cl}$ variability observed in the rain for those ions, especially at SM. Furthermore, these ions present low concentrations in the river waters and are consequently very sensitive to the application of atmospheric correction. For $\mathrm{K}^{+}$, the influence of the vegetation is another factor adding uncertainties in evaluating the atmospheric input (Negrel et al., 1993, Gaillardet et al., 1997).

\section{CONCLUSIONS}

This study allowed to obtain for the first time continue (4 years) and reliable data on both the geochemical and sedimentary fluxes of the two main rivers of French Guiana.

Both rivers present relatively stable inter-annual hydrological regime, probably due to the proximity of the Atlantic Ocean. During the hydrological cycle, the observed variability of the suspended material as well as of the TDS is low, although it exceeds that of the water flow. As observed on other rivers flowing on the Brazilian and Guiana shields, the sedimentary fluxes are very low and correspond to physical erosion rates ranging from $14(\mathrm{LT})$ to $21(\mathrm{SM}) \mathrm{t} \mathrm{km}^{-2}$ year $^{-1}$. The mineralogical and chemical composition of the transported sediments is also typical of the material usually found in tropical areas, with kaolinite as the main mineralogical species and $\mathrm{Al}$ and $\mathrm{Fe}$ as the main elements exported in the suspended load.

The chemical composition of the waters reflects the geological settings of the area, characterized by the alteration of the igneous rocks of the Guiana shield. This results in very low concentrations of major elements and thus in relatively limited dissolved material discharge for both rivers. The clear relationship observed between the mean normalized inorganic charge balance and the DOC results from the dissociation of organic acids. The greater influence of trade winds at the Saut Maripa station induces a different $\mathrm{Cl}$ :Na pattern with respect to the one observed at Langa Tabiki.

The atmospheric inputs are higher for the Opoyack river than the Maroni river. $\mathrm{Na}^{+}$is most impacted by rain contribution, $\mathrm{Ca}^{2+}$ and $\mathrm{Mg}^{2+}$ in rivers are mainly related to the rock-water interaction. It is difficult to give conclusions about the atmospheric contribution on the $\mathrm{K}^{+}, \mathrm{SO}_{4}{ }^{2-}$ and $\mathrm{NO}_{3}^{-}$rivers contents because of the low concentrations found in the river and of the great variability observed in the rain for these ions.

\section{ACKNOWLEDGEMENTS}

The authors wish to thank the French Institute of Universe Sciences (INSU) and the French Ministry of Research (MESR) for the financial support of this research. Many thanks also to the hydrologist and chemist technicians of the IRD Center in Cayenne 
for the field and lab assistance and to B. Guerrero (IRD-LMTG) for extracting the SRTM map of the area. 


\section{REFERENCES}

Bariac, T., Millet, A., Ladouche, B., Mathieu, R., Grimaldi, C., Grimaldi, M., Sarrazin, M., Hubert, P., Molicova, H., Bruckler, L., Valles, V., Bertuzzi, P., Bes, B, Gaudu, J.C., Horoyan, J., Boulegue, J., Jung, F., Brunet, Y., Bonnefond, J.M., Tournebize, R., Granier, A. (1996) Décomposition géochimique de l'hydrogramme de crue sur un petit bassin versant Guianais (piste Saint-Elie, dispositif ECEREX, Orstom-CTFT, Guyane Française). In L'hydrologie tropicale : géosciences et outil pour le développement. AISH Publ. 238, 249-269.

Barret, G. (2002) Relief et Hydrographie de la Guyane In: Atlas illustré de la Guyane (ed. by J. Barret), 34-36. Laboratoire de Cartographie de la Guyane, Cayenne, French Guiana.

Berthois, L., \& Hoorelbeck, J. (1964) Etude dynamique de la sédimentation dans trois cours d'eau de la Guyane française : Le Mahury, la rivière de Cayenne et le fleuve Maroni. Publication ORSTOM, Cayenne, $246 \mathrm{p}$.

Callède, J., Guyot, J.L., Ronchail, J., L'Hôte, Y., Lubès-Niel, H. \& Oliveira, E. (2004) Evolution du débit de l'Amazone à Obidos de 1903 à 1999. Hydrological Sciences Journal 49(1), 85-97.

Chave, J., 2005. Ecologie des communautés en forêt tropicale, Université Paul Sabatier, Toulouse, France.

Dupré, B., Gaillardet, J., Rousseau, D. \& Allègre, C.J. (1996) Major and trace elements of river-borne material : The Congo Basin. Geochimica et Cosmochimica Acta 60(8), 1301-1321.

Edmond, J.M., Palmer, M.R., Measure, C.I., Grant, B. \& Stallard, R.F. (1995) The fluvial geochemistry and denudation rate of the Guiana Shield in Venezuela, Colombia, and Brazil. Geochimica et Cosmochimica Acta 59(16), 3301-3325.

Filizola N. 2003. Transfert sédimentaire actuel par les fleuves amazoniens. Thèse de doctorat, Université P. Sabatier, Toulouse. 292 p.

Fritsch, J.M. (1982) Données hydrologiques pour l'aménagement de Petit Saut sur le Sinnamary. Publication ORSTOM, Cayenne, $57 \mathrm{p}$.

Fritsch, J.M. (1983) Evolution des écoulements, des transports solides à l'exutoire et de l'érosion sur les versants d'un petit bassin après défrichement mécanisé de la forêt tropicale humide. In Hydrology of humid tropical regions. IAHS Publ. 140, 197-214.

Fritsch, J.M. (1985) Etude d'impact de l'aménagement de Petit Saut sur le Sinnamary. Publication ORSTOM, Cayenne, 47 p.

Fritsch, J.M. (1987) Ecoulements et érosion sous prairies artificielles après défrichement de la forêt tropicale humide. In Forest hydrology and watershed management. IAHS Publ. 167, 123-129.

Fritsch, J.M. (1992) Les effets du défrichement de la forêt amazonienne et de la mise en culture sur l'hydrologie de petits bassins versants : opération ECEREX en Guyane française. Thèse de doctorat, Université de Montpellier. Publ. ORSTOM, Paris, 392 p.

Fritsch, J.M., Sarrailh, J.M. (1986) Les transports solides dans l'écosystème forestier tropical humide Guyanais: effets du défrichement et de l'aménagement de pâturages. Cahiers ORSTOM, Série Pédologie, 1986, 22 (2), 209-222. 
Gaillardet, J., Dupré, B., Allègre, C.J. \& Négrel, P. (1997) Chemical and physical denudation in the Amazon River basin. Chemical Geology 142, 141-173.

Gibbs, A.K. \& Barron, C.N. (1993) The Geology of the Guiana Shield. Oxford Monography of Geology and Geophysic 22.

Gibbs, A.K., Montgomery, C.W., O'Day, P.A. \& Erslev, E.A. (1986) The ArcheanProterozoic transition: evidence from the geochemistry of metasedimetary rocks of Guayna and Montana. Geochimica et Cosmochimica Acta 50, 21252142 .

Grimaldi, C. (1988). Origine de la composition chimique des eaux superficielles en milieu tropical humide : exemple de deux petits bassins versants sous forêt en Guyane Française. Sciences Géologiques Bulletin 41(3-4): 247-262.

Groussin, J. (2002) Le climat Guyanais. In: Atlas illustré de la Guyane (ed. by J. Barret), 46-49. Laboratoire de Cartographie de la Guyane, Cayenne, French Guiana.

Guyot, J.L., Filizola, N., Quintanilla, J., Cortez, J. (1996) Dissolved solids and suspended sediment yields in the Rio Madeira basin, from the Bolivian Andes to the Amazon. In Erosion and Sediment yield : Global and Regional Perspectives (IAHS Symposium, Exeter, UK, 07/1996). IAHS Publ. 236, 5563.

Guyot, J.L., Jouanneau, J.M., Soares, L., Boaventura, G., Maillet, N., Lagane, C. (2007) Clay mineral composition of river sediments in the Amazon Basin. Catena, $71: 340-356$.

Guillemet, M. (2002). Historique de la population. In: Atlas illustré de la Guyane (ed. by J. Barret), 144-149. Laboratoire de Cartographie de la Guyane, Cayenne, French Guiana.

Hiez, G. (1955) Etude préliminaire des régimes hydrologiques en Guyanne. Publication ORSTOM, Cayenne, $90 \mathrm{p}$.

Hiez, G. \& Dubreuil, P. (1963) Les régimes hydrologiques en Guyane Française. Publication ORSTOM-Paris, 308.

Humbel, F.X. (1989) Qualité et dynamique des eaux fluviales de Guyane Française. Publication ORSTOM, Cayenne, 67 p.

Martin, J.M., Meybeck, M. (1979) Elemental mass balance of material carried by world major rivers. Marine Chemistry, 7, 173-206.

Laraque, A., Mietton, M., Olivry, J.C., Pandi, A. 1998. Influence lithologique sur les régimes hydrologiques et la qualité des eaux des affluents congolais du fleuve Congo-Zaïre. Revue des Sciences de l'Eau, 11, p. 209-224.

Laraque, A., Bricquet, J.P., Pandi, A., Olivry, J.C., 2009. A review of material transport by the Congo River and its tributaries. Hydrological Processes, Special Issue on "Flow and Sediment Dynamics of Large Rivers", 23: 32163224.

Lointier, M. 1990. Evolution de la qualité des eaux et dynamique de l'intrusion saline dans l'estuaire de Sinnamary. Publication ORSTOM, Cayenne, 53 p.

Lointier, M. (1995) Variations saisonnières et flux de quelques élements majeurs dans trois rivières de Guyane Française. In Grands bassins fluviaux périatlantiques : Congo, Niger, Amazone. Colloques et Séminaires ORSTOM, Paris, 391-410.

Lointier, M., Roche, M.A. (1989) Salinités et suspensions des estuaires de Guyane : méthodes et résultats. In Quatrièmes journées hydrologiques de l'ORSTOM à Montpellier. Colloques et Séminaires, Publication ORSTOM, Paris, 81-124. 
Meybeck, M., 1983. Atmospheric inputs and river transport of dissolved substance. In: B.W. Webb (Editor). Dissolved loads of Rivers and Surface Water Quantity / Quality Relationships. IAHS, Hamburg, pp. 173-192.

Millet, A., Bariac, T. Ladouche, B., Mathieur, R. Grimaldi, C., Grimaldi, M., Hubert, P. Molicova, H., Bruckler, L., Valles, V., Bertuzzi, P., Brunet, Y. and Boulègue, J. 1998. Influence de la déforestation sur le fonctionnement hydrologique de petits bassins versants tropicaux. Revue des sciences de l'eau, 1: 61-84.

Millet, A., Bariac, T., Grimaldi, C. and Boulègue, J., 1999. Signature isotopique et chimique des précipitations (pluies et pluviolessivats) en Guyane Française. Revue des sciences de l'eau, 12(4): 729-751.

Monfort, M. Ruf, L. (2005) Régime hydrologique des fleuves guyanais: étude fréquencielle des débit. DIREN, Guyane, $36 \mathrm{p}$

Négrel, P., Allègre, C. J., Dupré, B., Lewin, E., 1993. Erosion sources determined from inversion of major, trace element ratios and strontium isotopic ratio in riverwater: the Congo Basin case. Earth and Planetary Science Letters, 120: 59-76.

Negrel, P., Lachassagne, P. and Laporte, P., 1997. Caractérisation chimique et istopique des pluies de Cayenne (Guyane française). Comptes Rendus de l'Académie des Sciences - Series IIa, 324: 379-386.

Négrel, P. and Lachassagne, P., 2000. Geochemistry of the Maroni River (French Guiana) during the low water stage: implications for water-rock interaction and groundwater characteristics. Journal of Hydrology, 237: 212-233.

Probst, J.L., Nkounkou, R.R., Krempp, G., Bricquet, J.P., Thiebaut, J.P. \& Olivry, J.C. (1992) Dissolved major elements exported by the Congo and the Ubangui rivers during the period 1987-1989. Journal of Hydrology 135, 237-257.

Roche, M.A. (1978 a) Etude hydrologique du Sinnamary à Petit Saut et Saut Tigre en vue de l'implantation d'un barrage hydroélectrique. Publication ORSTOM, Cayenne, $22 \mathrm{p}$.

Roche, M.A. (1978b) Les bassins versants expérimentaux Ecérex en Guyane française : étude comparative des écoulements et de l'érosion sous forêt tropicale humide. Cahiers ORSTOM, Série Hydrologie, 1978, 15 (4), 365-378.

Roche, M.A. (1982) Comportements hydrologiques comparés et érosion de l'écosystème forestier amazonien à Ecérex, en Guyane. Cahiers ORSTOM, Série Hydrologie, 1982, 19 (2), 81-114.

Roche, M.A., Dubreuil, P., Hoepffner, M. (1974) Dynamique des eaux, des sels et des sédiments en suspension dans les estuaires du Mahury et de l'Approuague. Publication ORSTOM, Cayenne, 80 p.

Stallard, R.F. and Edmond, J.M., 1981. Geochemistry of the Amazon 1. Precipitation chemistry and the marine contribution to the dissolved load at the of peak discharge. Journal of Geophysical Research, 86 (C10): 9844-9858.

Vauchel, P. (1998) Etude de l'hydrodynamique de l'estuaire du fleuve Mahury. DIREN Guyane / ORSTOM, Cayenne, $30 \mathrm{p}$.

Viers, J. Dupré, B., Braun, J.J., Freydier, R., Greenberg, S., Ndam-Ngoupayou, J. and Sigha-Nkamdjou, L., 2001. Evidence for Non-Conservative Behaviour of Chlorine in Humid Tropical Environments. Aquatic Geochemistry(7): 127154. 


\section{List of tables}

Table 1: Main characteristics of the studied basins

\begin{tabular}{|c|c|c|c|c|c|c|c|c|c|c|}
\hline \multirow[t]{2}{*}{ Code } & \multirow[t]{2}{*}{ River } & \multirow{2}{*}{$\begin{array}{c}\text { Latitude } \\
\text { (degree N) }\end{array}$} & \multirow{2}{*}{$\begin{array}{l}\text { Longitude } \\
\text { (degree W) }\end{array}$} & \multirow{2}{*}{$\begin{array}{c}\text { Drainage } \\
\text { basin }\left(\mathrm{km}^{2}\right)\end{array}$} & \multirow{2}{*}{$\begin{array}{c}\text { Rainfall } \\
\left(\mathrm{mm}^{\text {year }}{ }^{-1}\right)\end{array}$} & \multirow[t]{2}{*}{ Period } & \multicolumn{3}{|c|}{ Discharge } & \multirow{2}{*}{$\begin{array}{l}\mathbf{K e} \\
(\%) \\
\end{array}$} \\
\hline & & & & & & & $\left(\mathrm{m}^{3} \cdot \mathrm{s}^{-1}\right)$ & $\left(1 . \mathrm{s}^{-1} \cdot \mathrm{km}^{-2}\right)$ & (mm.ye & \\
\hline $\mathrm{LT}$ & & 5.1401 & 54.3551 & & 2520 & & 1700 & 26.5 & 840 & 33.3 \\
\hline SM & Oyapock River at Saut Maripa & 3.7995 & 51.8883 & 24630 & 2680 & $1953-2007$ & 830 & 33.7 & 1060 & 39.6 \\
\hline
\end{tabular}

Table 2: Discharge, TDS and TSS yields for the 2004-2007 period

\begin{tabular}{|c|c|c|c|}
\hline & \multirow[b]{2}{*}{ Unit } & Maroni river & \multirow{2}{*}{$\begin{array}{c}\text { Oyapock river } \\
\text { Mean Max Min RSD }\end{array}$} \\
\hline & & Mean Max Min RSD & \\
\hline Daily discharge & $\mathrm{m}^{3} \mathrm{~s}^{-1}$ & $1840 \quad 6160 \quad 600,69$ & $7903270 \quad 700,77$ \\
\hline TSS & $\mathrm{mg} \mathrm{l}^{-1}$ & $21,9 \quad 132,2 \quad 1,60,89$ & $12,1102,4 \quad 1,91,17$ \\
\hline Sediment yield (QS) & $\mathrm{t}_{\text {day }}{ }^{-1}$ & $375014730 \quad 240,86$ & $\begin{array}{llll}9407 & 140 & 13 & 1,04\end{array}$ \\
\hline TDS & $\mathrm{mg} \mathrm{l}^{-1}$ & $25,8 \quad 33,817,50,17$ & $21,6 \quad 34,013,00,17$ \\
\hline Dissolved yield (QD) & $\mathrm{t} \mathrm{day}^{-1}$ & 3910106501600,58 & 143063101500,72 \\
\hline$\overline{Q S+Q D}$ & t day $^{-1}$ & 7660 & 2370 \\
\hline $\mathrm{QS} /(\mathrm{QS}+\mathrm{QD})$ & $\%$ & 49 & 40 \\
\hline Solid transport yield (QS) & $\left(\mathrm{t} \mathrm{km}^{2} \cdot \mathrm{yr}^{-1}\right)$ & 21 & 14 \\
\hline Dissolved transport yield (QD) & $\left(\mathrm{t} \mathrm{km}^{2} \cdot \mathrm{yr}^{-1}\right)$ & 22 & 21 \\
\hline Total (QS + QD) & $\left(\mathrm{t} \mathrm{km}^{2} \cdot \mathrm{yr}^{-1}\right)$ & 44 & 35 \\
\hline
\end{tabular}

Table 3: Mean, minimum and maximum value for major elements in the suspended sediments (in \%), and elemental fluxes (QS_el in $\mathrm{t} \mathrm{km}^{-2} \mathrm{y}^{-1}$ )

\begin{tabular}{c|ccccc|ccccc}
\hline Element & \multicolumn{6}{|c|}{ Maroni river } & \multicolumn{4}{c}{ Oyapock river } \\
& Mean & Min & Max & RSD & QS_el & Mean & Min & Max & RSD & QS_el \\
\hline $\mathrm{Al}$ & 13.51 & 5.2 & 27.81 & 0.39 & 2,88 & 14.78 & 7.54 & 24.67 & 0.37 & 2,06 \\
$\mathrm{Fe}$ & 6.24 & 2.45 & 11.98 & 0.43 & 1,33 & 7.25 & 2.37 & 14.86 & 0.45 & 1,01 \\
$\mathrm{Ca}$ & 0.63 & 0.13 & 3.58 & 1.24 & 0,13 & 0.45 & 0.18 & 1.09 & 0.55 & 0,06 \\
$\mathrm{Mg}$ & 0.27 & 0.1 & 0.75 & 0.54 & 0,06 & 0.22 & 0.12 & 0.49 & 0.46 & 0,03 \\
$\mathrm{Na}$ & 0.23 & 0.04 & 0.62 & 0.69 & 0,05 & 0.20 & 0.03 & 1.11 & 1.16 & 0,03 \\
$\mathrm{~K}$ & 1.23 & 0.22 & 7.64 & 1.37 & 0,26 & 0.48 & 0.26 & 1.06 & 0.49 & 0,07 \\
$\mathrm{Mn}$ & 0.14 & 0.04 & 0.56 & 0.81 & 0,03 & 0.14 & 0.05 & 0.51 & 0.89 & 0,02 \\
\hline
\end{tabular}


Table 4: Mean, maximum and minimum values for the major elements in the dissolved load, and elemental fluxes (QD_el in $\mathrm{t} \mathrm{day}^{-1}$ )

\begin{tabular}{|c|c|c|c|c|c|c|c|c|c|c|c|}
\hline & \multirow[b]{2}{*}{ Unit } & \multicolumn{5}{|c|}{ Langa Tabiki } & \multicolumn{5}{|c|}{ Saut Maripa } \\
\hline & & Mean & $\operatorname{Max}$ & Min & RSD & QD_el & Mean & Max & Min & RSD & QD_el \\
\hline $\mathrm{pH}$ & & 6.2 & 7.0 & 5.1 & 0.07 & & 6.2 & 6.9 & 5.5 & 0.06 & \\
\hline Conductivity & $\mu \mathrm{S} \mathrm{cm}^{-1}$ & 28.6 & 82.0 & 21.0 & 0.38 & & 23.3 & 42.0 & 17.0 & 0.24 & \\
\hline $\mathrm{Fe}$ & $\operatorname{mg} .1^{-1}$ & 0.13 & 1 & 0.01 & 1.48 & 18.7 & 0.1 & 0.6 & 0.01 & 1.05 & 6,8 \\
\hline $\mathrm{Si}$ & $\mathrm{mg} . \mathrm{l}^{-1}$ & 4.83 & 6.22 & 3.12 & 0.16 & 730.1 & 4.36 & 6.01 & 2.73 & 0.18 & 304,4 \\
\hline $\mathrm{Al}$ & $\operatorname{mg} .1^{-1}$ & 0.09 & 0.59 & 0.01 & 1.16 & 16.9 & 0.12 & 0.55 & 0.02 & 1.03 & 10,8 \\
\hline $\mathrm{Ca}$ & $\operatorname{mg} .1^{-1}$ & 1.17 & 2.28 & 0.58 & 0.18 & 166.2 & 0.86 & 2.04 & 0.48 & 0.36 & 62,6 \\
\hline $\mathrm{Mg}$ & $\operatorname{mg} .1^{-1}$ & 0.64 & 0.84 & 0.36 & 0.20 & 93.4 & 0.5 & 0.67 & 0.33 & 0.18 & 33,6 \\
\hline $\mathrm{Na}$ & $\operatorname{mg} .1^{-1}$ & 2.08 & 3.43 & 1.27 & 0.20 & 300.0 & 1.96 & 2.43 & 1.19 & 0.18 & 134,7 \\
\hline $\mathrm{K}$ & $\operatorname{mg} .1^{-1}$ & 0.86 & 1.86 & 0.46 & 0.32 & 121.2 & 0.63 & 1.05 & 0.28 & 0.30 & 42,9 \\
\hline $\mathrm{F}$ & $\operatorname{mg} .1^{-1}$ & 0.02 & 0.02 & 0.02 & 0.03 & 2.9 & $<0.01$ & - & - & - & - \\
\hline $\mathrm{Cl}$ & $\operatorname{mg} .1^{-1}$ & 1.84 & 2.28 & 1.45 & 0.14 & 284.4 & 2.28 & 3.14 & 1.49 & 0.16 & 157,8 \\
\hline NO3 & $\operatorname{mg} .1^{-1}$ & 0.51 & 1.39 & 0.14 & 0.58 & 88.3 & 0.36 & 0.8 & 0.12 & 0.43 & 27,0 \\
\hline PO4 & $\operatorname{mg} .1^{-1}$ & $<0.1$ & - & - & - & - & $<0.1$ & - & - & - & - \\
\hline $\mathrm{SO} 4$ & $\operatorname{mg} .1^{-1}$ & 0.5 & 1.37 & 0.17 & 0.58 & 70.4 & 0.46 & 1.49 & 0.1 & 0.65 & 28,6 \\
\hline $\mathrm{HCO} 3$ & $\operatorname{mg} .1^{-1}$ & 8.82 & 14.45 & 4.25 & 0.30 & 1260.8 & 6.29 & 13.6 & 1.65 & 0.37 & 427,0 \\
\hline DOC & $\operatorname{mg} .1^{-1}$ & 6.44 & 13.87 & 2.75 & 0.40 & 1020.0 & 8.21 & 50.43 & 2.46 & 0.39 & 359,0 \\
\hline$\overline{\sum \text { cations }}$ & $\mu \mathrm{e} .1^{-1}$ & 223.3 & 348 & 160.7 & 0.19 & & 184.9 & 253.6 & 122.4 & 0.18 & \\
\hline$\underline{\sum \text { anions }}$ & $\mu \mathrm{e}^{-1^{-1}}$ & 213.6 & 308.5 & 141.3 & 0.21 & & 182.0 & 302.4 & 99.0 & 0.24 & \\
\hline $\mathrm{Ca} / \mathrm{Na}$ & & 0.324 & 0.437 & 0.174 & 0.16 & & 0.254 & 0.488 & 0.134 & 0.30 & \\
\hline NICB & & $5 \%$ & $44 \%$ & $-19 \%$ & 2.14 & & $4 \%$ & $44 \%$ & $-24 \%$ & 2.99 & \\
\hline
\end{tabular}

Table 5 : Comparaison of the composition of the dissolved phase at Langa Tabiki and Saut Maripa with data from other tropical shield basins

\begin{tabular}{|c|c|c|c|c|c|c|c|c|c|c|c|}
\hline & Unit & $\begin{array}{l}\text { Maroni R. } \\
\text { (a) }\end{array}$ & $\begin{array}{c}\text { Oyapock R. } \\
\text { (a) }\end{array}$ & $\begin{array}{l}\text { Negro R. } \\
\text { (b) }\end{array}$ & $\begin{array}{l}\text { Solimões R. } \\
\text { (b) }\end{array}$ & $\begin{array}{l}\text { Madeira R. } \\
\text { (b) }\end{array}$ & $\begin{array}{l}\text { Amazon R. } \\
\text { at Obidos (b) }\end{array}$ & $\begin{array}{c}\text { Caroni R. } \\
\text { at Capaura (c) }\end{array}$ & $\begin{array}{l}\text { Oubangui R } \\
\text { (d) }\end{array}$ & $\begin{array}{c}\text { Kasai R } \\
\text { (d) }\end{array}$ & $\begin{array}{l}\text { Congo R. } \\
\text { (d) }\end{array}$ \\
\hline $\mathrm{pH}$ & & 6.2 & 6.2 & 4.9 & 7.1 & 6.7 & 6.8 & 4.63 & 6.3 & 6.4 & 6.4 \\
\hline $\mathrm{Si}$ & $\mathrm{mg} . \mathrm{l}^{-1}$ & 4.83 & 4.36 & 1.68 & 4.21 & 3.93 & & 0.29 & 6.36 & & 5.32 \\
\hline $\mathrm{Ca}$ & $\mathrm{mg} . \mathrm{l}^{-1}$ & 1.17 & 0.86 & 0.36 & 7.45 & 2.65 & 3.93 & 0.11 & 2.60 & 1.76 & 2.08 \\
\hline $\mathrm{Mg}$ & $\mathrm{mg} . \mathrm{l}^{-1}$ & 0.64 & 0.50 & 0.10 & 1.22 & 1.22 & 0.80 & 0.37 & 1.00 & 0.92 & 1.36 \\
\hline $\mathrm{Na}$ & $\mathrm{mg} . .^{-1}$ & 2.08 & 1.96 & 0.32 & 2.41 & 1.40 & 1.47 & 0.35 & & 1.22 & 1.13 \\
\hline $\mathrm{K}$ & $\mathrm{mg} . \mathrm{l}^{-1}$ & 0.86 & 0.63 & 0.47 & 0.90 & 0.90 & & 0.27 & 1.10 & 1.29 & 1.41 \\
\hline $\mathrm{Cl}$ & $\mathrm{mg} . \mathrm{l}^{-1}$ & 1.84 & 2.28 & 0.57 & 2.20 & 0.46 & 1.17 & & 0.77 & 0.91 & 1.16 \\
\hline $\mathrm{NO}_{3}$ & $\mathrm{mg} . .^{-1}$ & 0.51 & 0.36 & 0.31 & & & & 1.08 & & & \\
\hline $\mathrm{HCO}_{3}$ & $\mathrm{mg} . \mathrm{l}^{-1}$ & 8.82 & 6.29 & & 29.40 & 15.60 & 17.40 & 31 & 14.34 & 9.46 & 11.22 \\
\hline$\sum$ cations & $\mu \mathrm{e} . \mathrm{l}^{-1}$ & 223 & 185 & 66 & 600 & 293 & 326 & 26 & 303 & 208 & 301 \\
\hline$\sum$ anions & $\mu \mathrm{e} . \mathrm{l}^{-1}$ & 214 & 182 & 39 & 592 & 428 & 355 & 4.63 & 283 & 164 & 239 \\
\hline NICB & & $5 \%$ & $4 \%$ & $41 \%$ & $1 \%$ & $-16 \%$ & $9 \%$ & & $7 \%$ & $21 \%$ & $21 \%$ \\
\hline
\end{tabular}
(a) : this study
(b) :Gaillardet et al., 1997
(c) : Edmond et al, 1995
(d) : Dupré et al., 1996 
Table 6 : Correlation coefficients between major ions at Langa Tabiki (a) and Saut Maripa (b)

(in bold : significant coefficient, $\mathrm{n}=41, \rho 0=0.40$ for $\mathrm{t}=99.5 \%$ )

(a)

\begin{tabular}{ccccccccc} 
& $\mathrm{Mg}$ & $\mathrm{Na}$ & $\mathrm{K}$ & $\mathrm{Si}$ & $\mathrm{Cl}$ & $\mathrm{NO}_{3}$ & $\mathrm{SO}_{4}$ & $\mathrm{HCO}_{3}$ \\
\hline $\mathrm{Ca}$ & $\mathbf{0 . 4 0}$ & $\mathbf{0 . 8 0}$ & $\mathbf{0 . 7 3}$ & 0.29 & $\mathbf{0 . 4 6}$ & 0.22 & $\mathbf{0 . 4 0}$ & $\mathbf{0 . 4 9}$ \\
$\mathrm{Mg}$ & & 0.37 & 0.16 & $\mathbf{0 . 6 4}$ & 0.13 & 0.03 & 0.11 & $\mathbf{0 . 7 2}$ \\
$\mathrm{Na}$ & & & $\mathbf{0 . 8 0}$ & $\mathbf{0 . 4 0}$ & $\mathbf{0 . 7 8}$ & 0.01 & $\mathbf{0 . 5 2}$ & $\mathbf{0 . 4 4}$ \\
$\mathrm{K}$ & & & & 0.11 & $\mathbf{0 . 6 7}$ & 0.31 & $\mathbf{0 . 8 3}$ & $\mathbf{0 . 4 0}$ \\
$\mathrm{Si}$ & & & & & 0.02 & 0.02 & 0.31 & 0.37 \\
$\mathrm{Cl}$ & & & & & & 0.28 & $\mathbf{0 . 6 9}$ & 0.26 \\
$\mathrm{NO}_{3}$ & & & & & & & $\mathbf{0 . 4 9}$ & -0.21 \\
$\mathrm{SO}_{4}$ & & & & & & & 0.01 \\
\hline
\end{tabular}

(b)

\begin{tabular}{ccccccccc} 
& $\mathrm{Mg}$ & $\mathrm{Na}$ & $\mathrm{K}$ & $\mathrm{Si}$ & $\mathrm{Cl}$ & $\mathrm{NO}_{3}$ & $\mathrm{SO}_{4}$ & $\mathrm{HCO}_{3}$ \\
\hline $\mathrm{Ca}$ & 0.24 & $\mathbf{0 . 4 4}$ & 0.37 & 0.20 & 0.23 & 0.14 & 0.04 & $\mathbf{0 . 4 7}$ \\
$\mathrm{Mg}$ & & $\mathbf{0 . 5 5}$ & $\mathbf{0 . 5 4}$ & $\mathbf{0 . 7 4}$ & $\mathbf{0 . 4 4}$ & 0.06 & 0.27 & 0.34 \\
$\mathrm{Na}$ & & & $\mathbf{0 . 8 0}$ & $\mathbf{0 . 4 0}$ & $\mathbf{0 . 7 8}$ & 0.01 & $\mathbf{0 . 5 2}$ & $\mathbf{0 . 4 4}$ \\
$\mathrm{K}$ & & & & 0.23 & $\mathbf{0 . 7 3}$ & 0.05 & $\mathbf{0 . 7 0}$ & 0.22 \\
$\mathrm{Si}$ & & & & & 0.23 & 0.14 & 0.04 & $\mathbf{0 . 4 7}$ \\
$\mathrm{Cl}$ & & & & & & 0.02 & $\mathbf{0 . 7 5}$ & 0.28 \\
$\mathrm{NO}_{3}$ & & & & & & & 0.06 & -0.22 \\
$\mathrm{SO}_{4}$ & & & & & & & 0.16 \\
\hline
\end{tabular}

Table 7 : Mean values of major elements exportation in the dissolved (QD_el) and suspended (QS_el) phases (in $\left.\mathrm{t} \mathrm{km}^{-2} \mathrm{y}^{-1}\right)$. STI = QD/(QD + QS)

\begin{tabular}{|c|c|c|c|c|c|c|}
\hline & \multicolumn{3}{|c|}{ Maroni R. } & \multicolumn{3}{|c|}{ Oyapock R. } \\
\hline & QS el & QD el & STI & QS el & QD el & STI \\
\hline $\mathrm{Al}$ & $2, \overline{34}$ & $0, \overline{10}$ & $4 \%$ & $2, \overline{06}$ & $0, \overline{16}$ & $7 \%$ \\
\hline $\mathrm{Fe}$ & 1,15 & 0,11 & $8 \%$ & 1,01 & 0,10 & $9 \%$ \\
\hline $\mathrm{Ca}$ & 0,06 & 0,94 & $94 \%$ & 0,06 & 0,93 & $94 \%$ \\
\hline $\mathrm{Mg}$ & 0,04 & 0,53 & $93 \%$ & 0,03 & 0,50 & $94 \%$ \\
\hline $\mathrm{Na}$ & 0,05 & 1,70 & $97 \%$ & 0,03 & 2,00 & $99 \%$ \\
\hline $\mathrm{K}$ & 0,11 & 0,69 & $86 \%$ & 0,07 & 0,64 & $90 \%$ \\
\hline
\end{tabular}


Table $8: \mathrm{X} / \mathrm{Cl}$ rain data for the Maroni catchment (Négrel \& Lachassagne, 2000) and for Cayenne (Négrel et al., 1997). Mean values are arithmetic mean (n.d. : non-determined value).

\begin{tabular}{llcccccc}
\hline \multicolumn{1}{l}{ Maroni basin } & $\mathrm{Ca} / \mathrm{Cl}$ & $\mathrm{Mg} / \mathrm{Cl}$ & $\mathrm{Na} / \mathrm{Cl}$ & $\mathrm{K} / \mathrm{Cl}$ & $\mathrm{NO}_{3} / \mathrm{Cl}$ & $\mathrm{SO}_{4} / \mathrm{Cl}$ \\
Location & Apagui & 0.065 & n.d. & 0.814 & 0.215 & 0.021 & 0,014 \\
& Manbari & 0.144 & 0.08 & 1.168 & 0.222 & 0.078 & 0,09 \\
& Poligodou Soula & 0.099 & 0.041 & 1.2 & 0.354 & 0.016 & 0,041 \\
& Grand Santi & n.d. & n.d. & 1.15 & n.d. & n.d. & n.d. \\
& Antecume Pata & 0.095 & n.d. & 1.267 & 0.553 & 0.02 & 0,027 \\
& Elae & 0.148 & n.d. & 1.284 & 0.609 & n.d. & n.d. \\
\hline Cayenne & & & & & & & \\
Month & January & 0.213 & 0.164 & 1.006 & 0.067 & 0 & 0,071 \\
& February & 0.042 & 0.143 & 0.872 & 0.149 & 0.016 & 0,009 \\
& March & 0.049 & 0.119 & 0.837 & 0.058 & 0.024 & 0,052 \\
& April & 0.081 & 0.083 & 0.547 & 0.091 & 0.017 & 0,056 \\
& May & 0.018 & 0.035 & 0.543 & 0.077 & 0.022 & 0,075 \\
& June & 0.042 & 0.069 & 0.495 & 0.051 & 0.119 & 0,091 \\
& July & 0.105 & $\mathrm{n} . \mathrm{d}$. & 0.421 & 0.337 & 0.124 & 0,074 \\
& October & 0.02 & 0.04 & 0.569 & 0.247 & 0.02 & 0,059 \\
& November & 0.085 & 0.093 & 0.648 & 0.276 & 0.044 & 0,042 \\
& December & 0.108 & 0.013 & 0.583 & 0.508 & n.d. & n.d. \\
\hline
\end{tabular}

Table 9: Relative atmospheric inputs on the Maroni (LT) and Opayock (SM) rivers. The RSD monthly values are the RSD calculated on the relative monthly contribution of rain inputs. The rain composition RSD is the integration of the variability of the $\mathrm{X} / \mathrm{Cl}$ in the calculation of the atmospheric contribution.

\begin{tabular}{|c|c|c|c|c|c|c|c|}
\hline & & $\mathrm{Ca}$ & $\mathrm{Mg}$ & $\mathrm{Na}$ & $\mathrm{K}$ & $\mathrm{NO}_{3}$ & $\mathrm{SO}_{4}$ \\
\hline \multirow[t]{3}{*}{$\mathrm{LT}$} & mean & $15 \%$ & $15 \%$ & $48 \%$ & $61 \%$ & $35 \%$ & $64 \%$ \\
\hline & RSD of monthly values & $3 \%$ & $5 \%$ & $6 \%$ & $11 \%$ & $18 \%$ & $21 \%$ \\
\hline & rain composition RSD & $13 \%$ & $14 \%$ & $20 \%$ & $53 \%$ & $54 \%$ & $47 \%$ \\
\hline \multirow[t]{3}{*}{ SM } & mean & $27 \%$ & $23 \%$ & $63 \%$ & $91 \%$ & $53 \%$ & $81 \%$ \\
\hline & RSD of monthly values & $6 \%$ & $4 \%$ & $8 \%$ & $11 \%$ & $24 \%$ & $19 \%$ \\
\hline & rain composition RSD & $22 \%$ & $18 \%$ & $26 \%$ & $89 \%$ & $77 \%$ & $69 \%$ \\
\hline
\end{tabular}




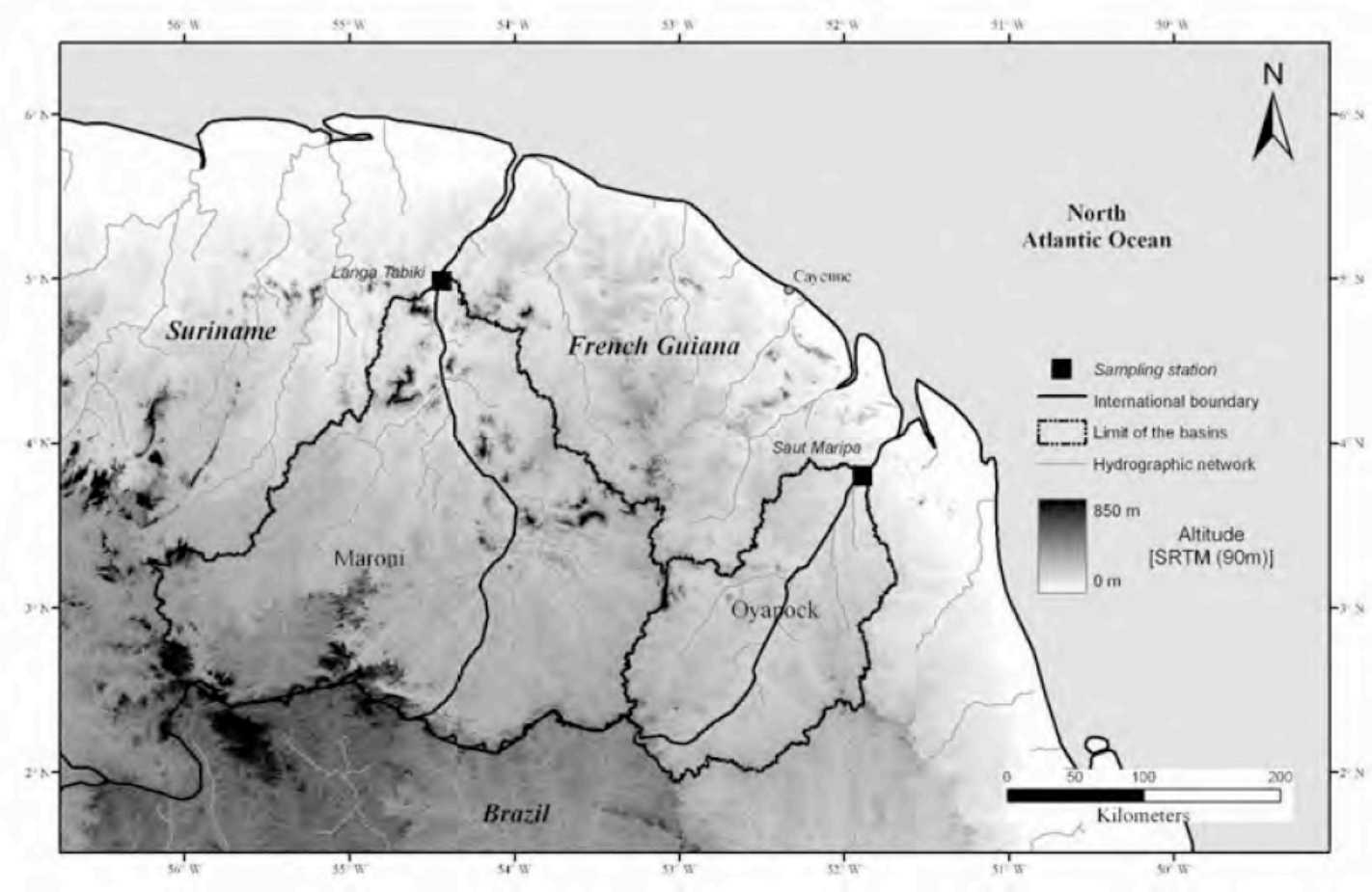

Fig. 1. Maroni and Oyapock rivers drainage basins (French Guiana)

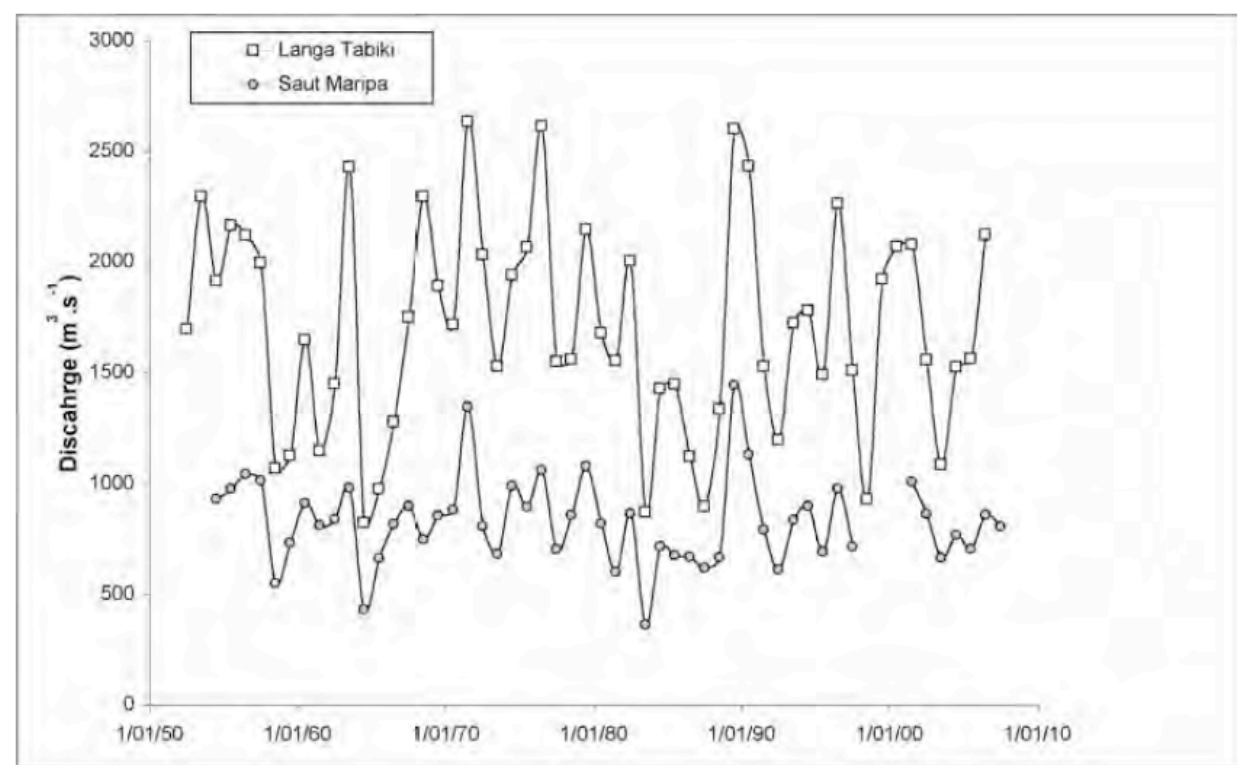

Fig. 2. Mean annual discharge (1951/1953-2007) Maroni River at Langa Tabiki and Oyapock River at Saut Maripa 


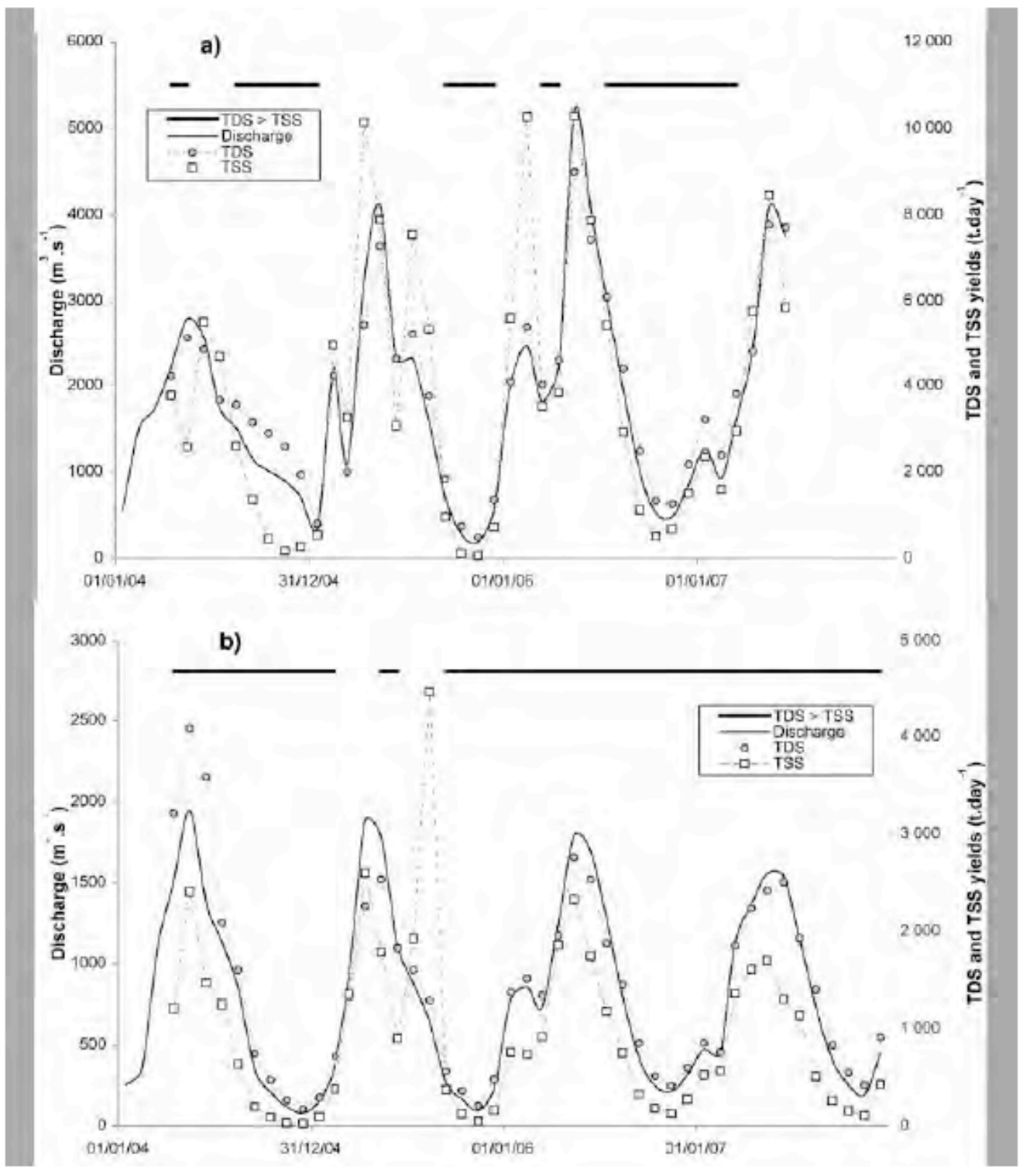

Fig. 3. Monthly discharge, dissolved and suspended sediment yields for (a) the Maroni River at Langa Tabiki (2004-2008 and (b) the Oyapock River at Saut Maripa (2004-2008). It should be noted that TDS is > to TSS nearly $95 \%$ of time for Oyapock and about $50 \%$ for Maroni. 

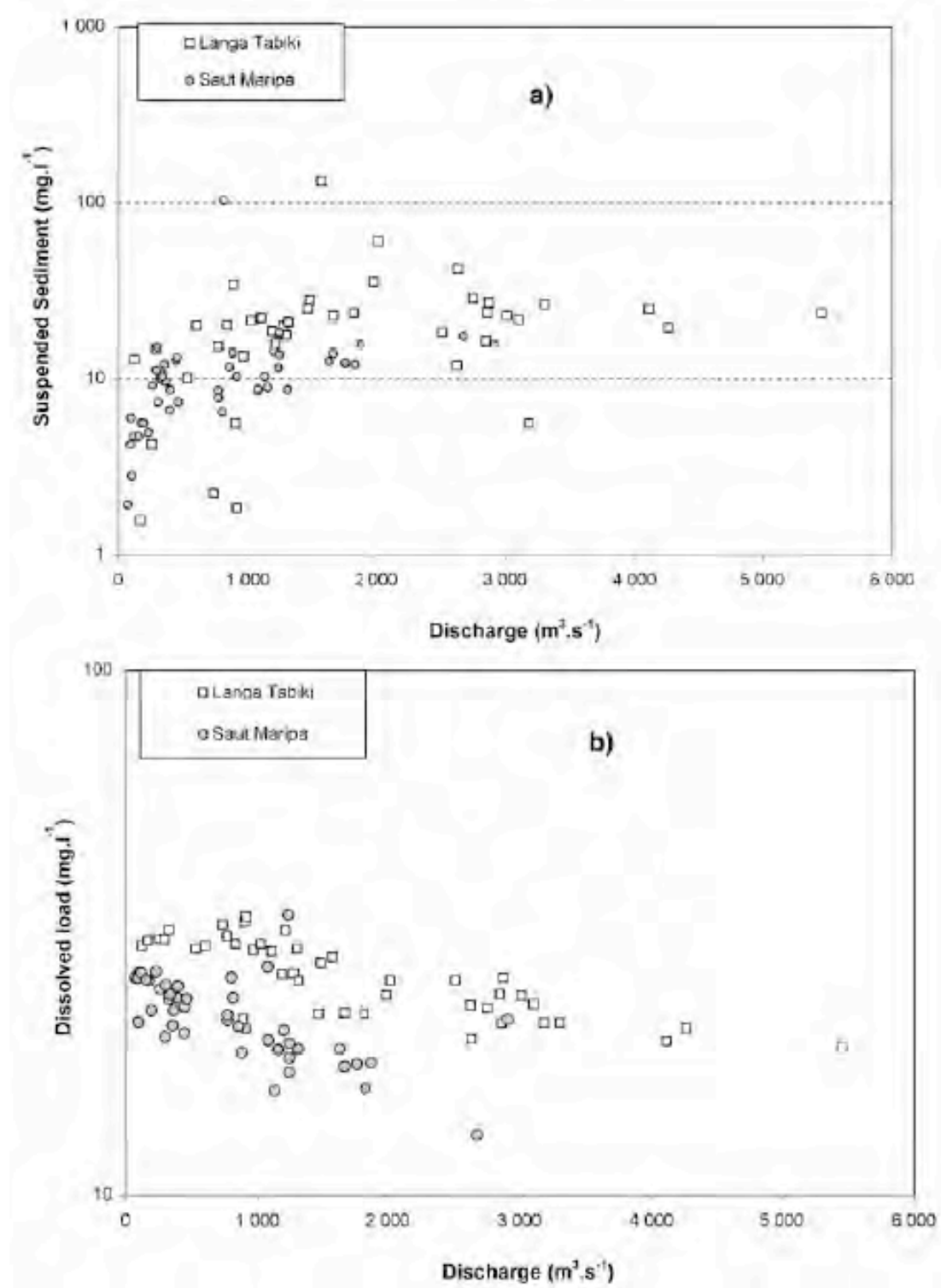

Fig. 4. Relation of the suspended sediment load with discharge (a) and of the dissolved load with discharge (b) 

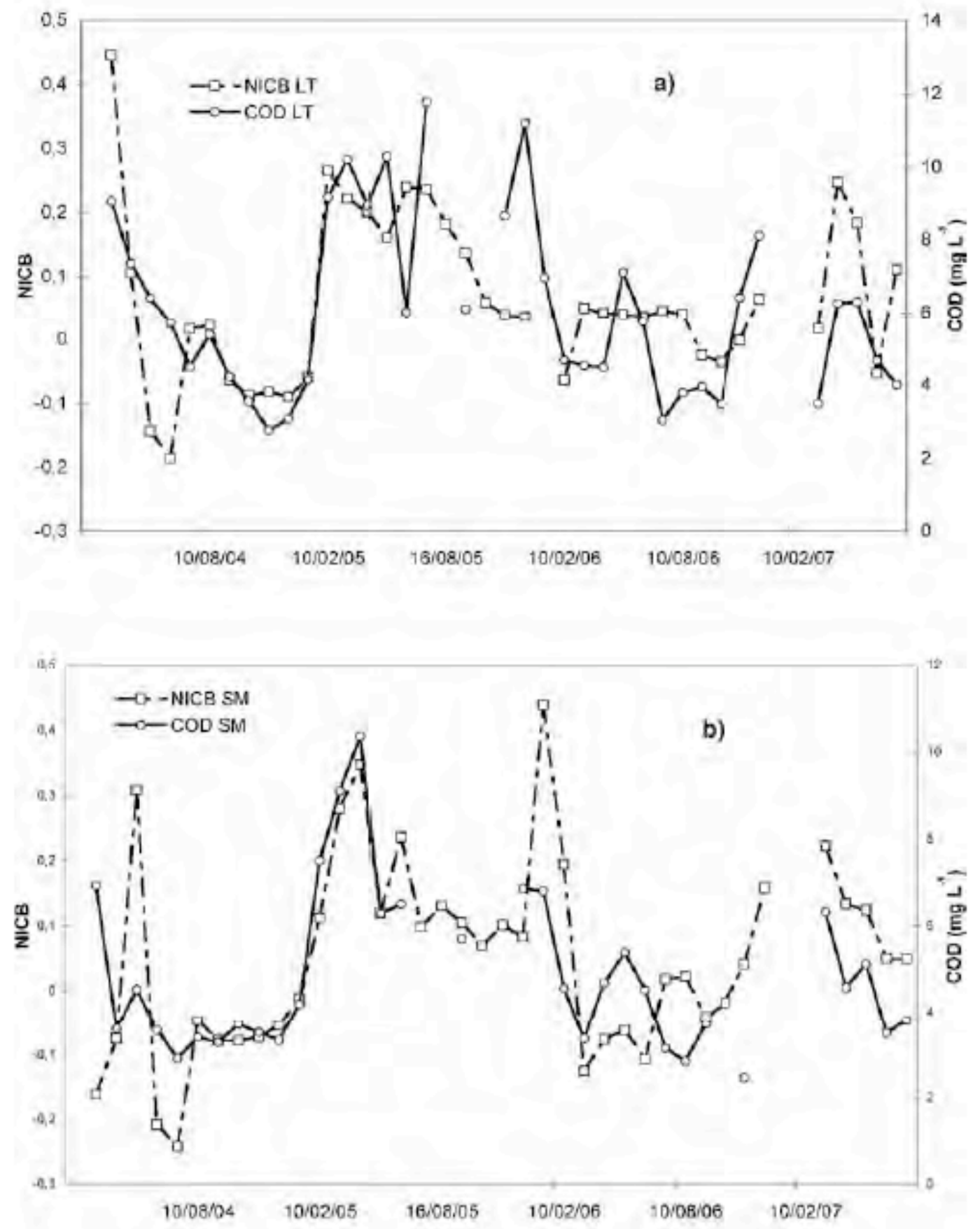

Fig. 5. NICB vs COD (mg L-1) content at Langa Tabiki (a) and Saut Maripa (b) 

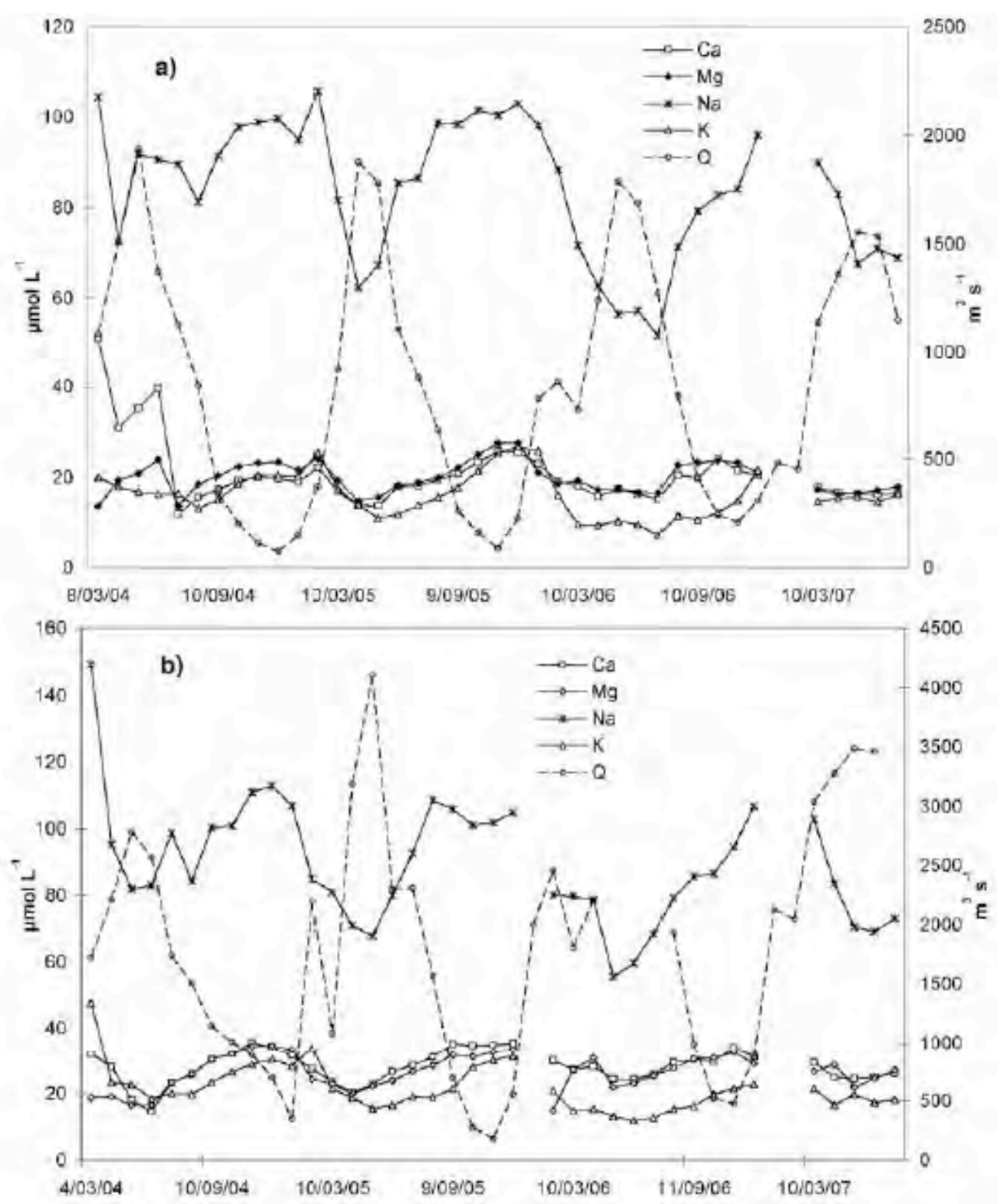

Fig. 6. Major cations content and water discharge at Saut Maripa (a) and Langa Tabiki (b) 


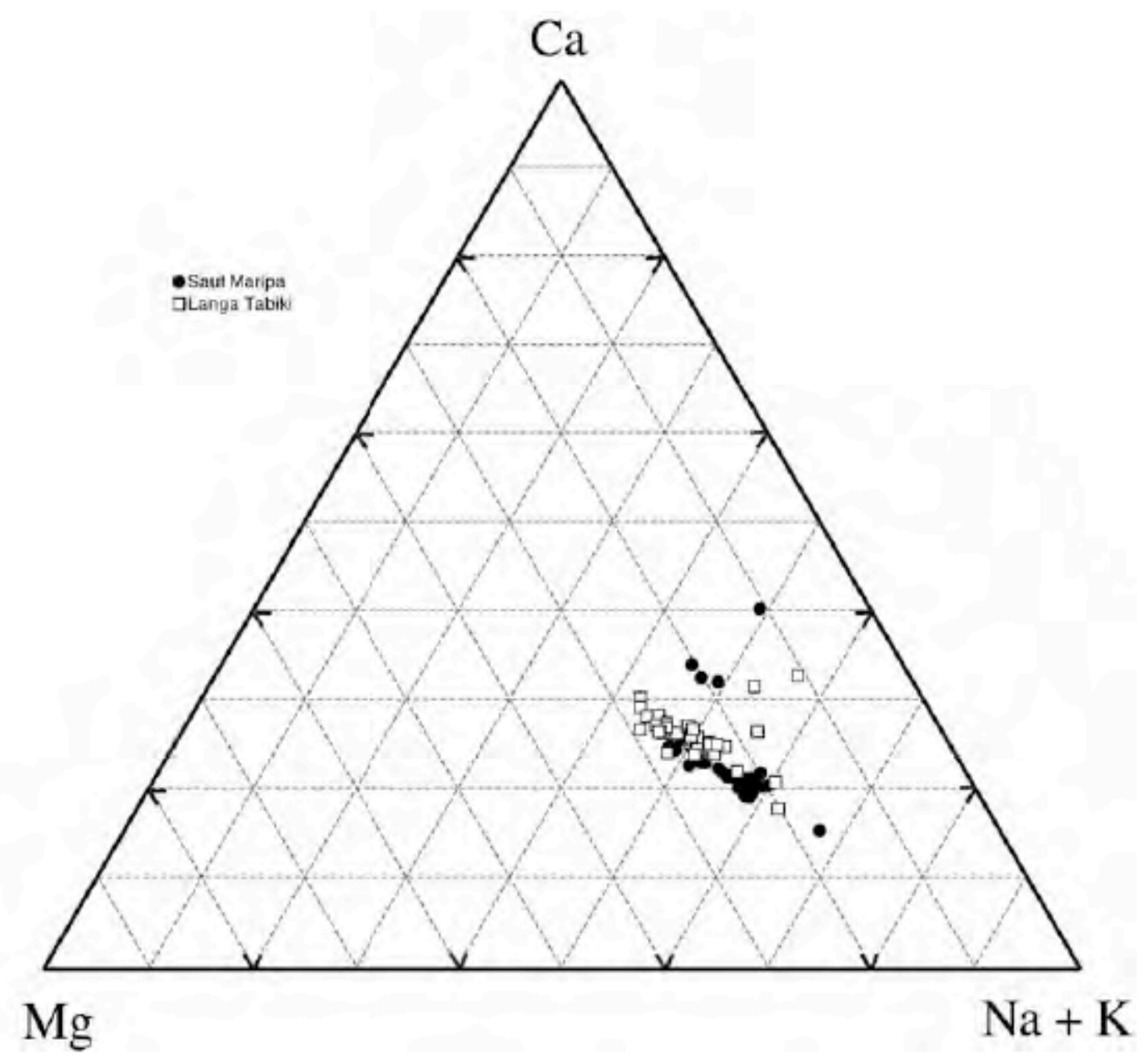

Fig. 7. $\mathrm{Ca}, \mathrm{Mg}$ and $\mathrm{Na}+\mathrm{K}$ ternary plot 


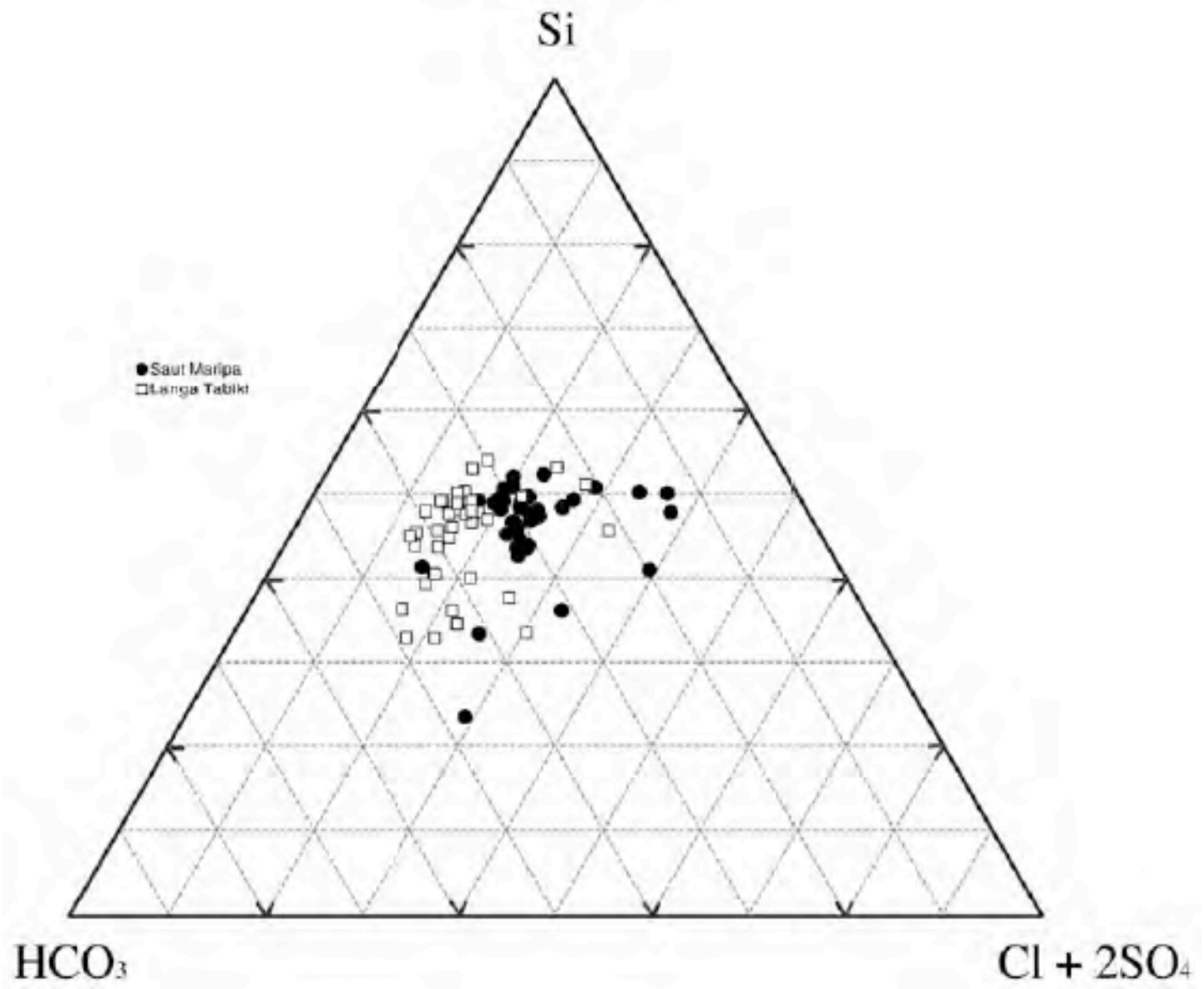

Fig. 8. Ternary plot of $\mathrm{Si}$, alkalinity and $\mathrm{Cl}+2 \mathrm{SO} 4$

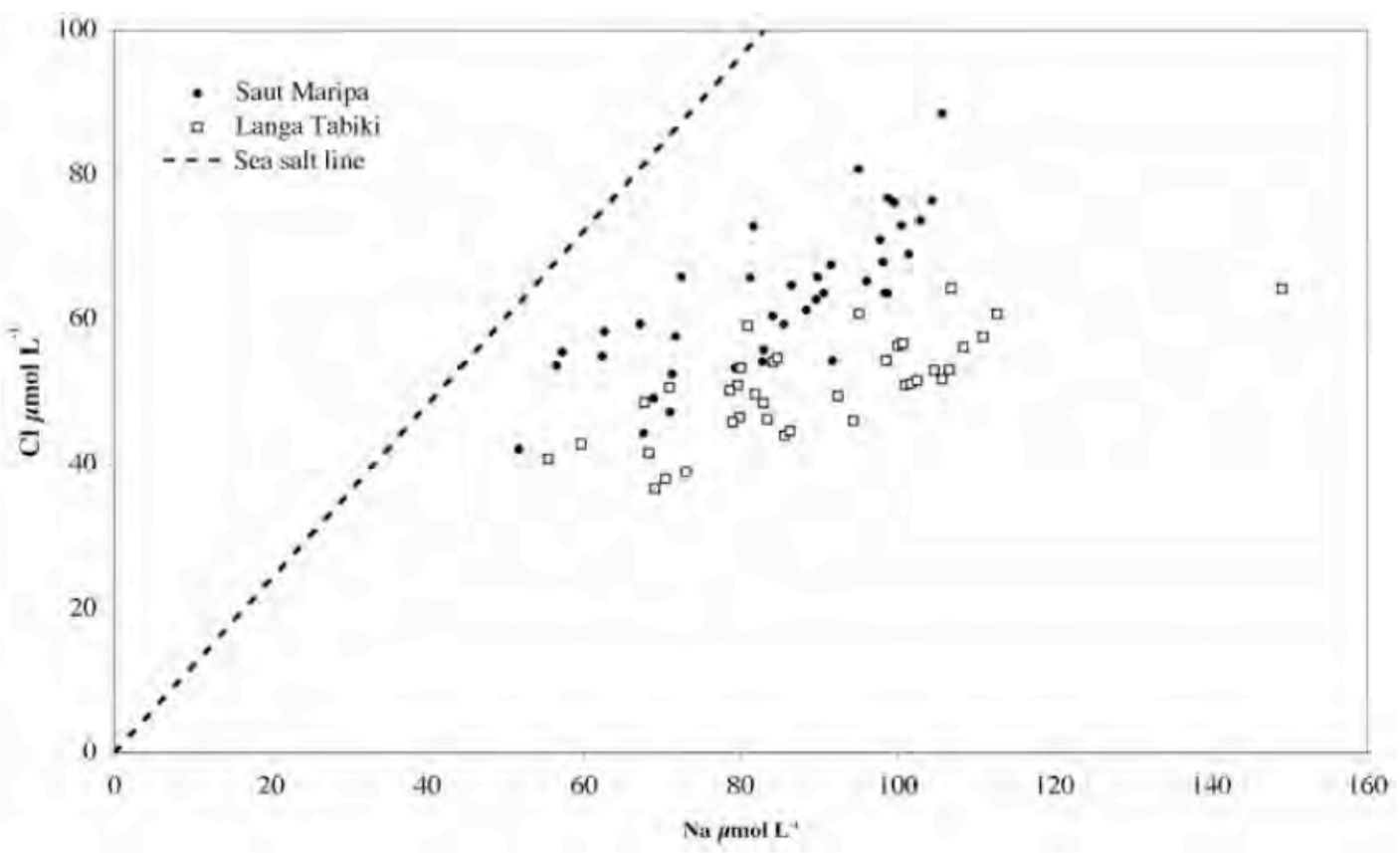

Fig. 9. $\mathrm{Na} / \mathrm{Cl}$ ratio 


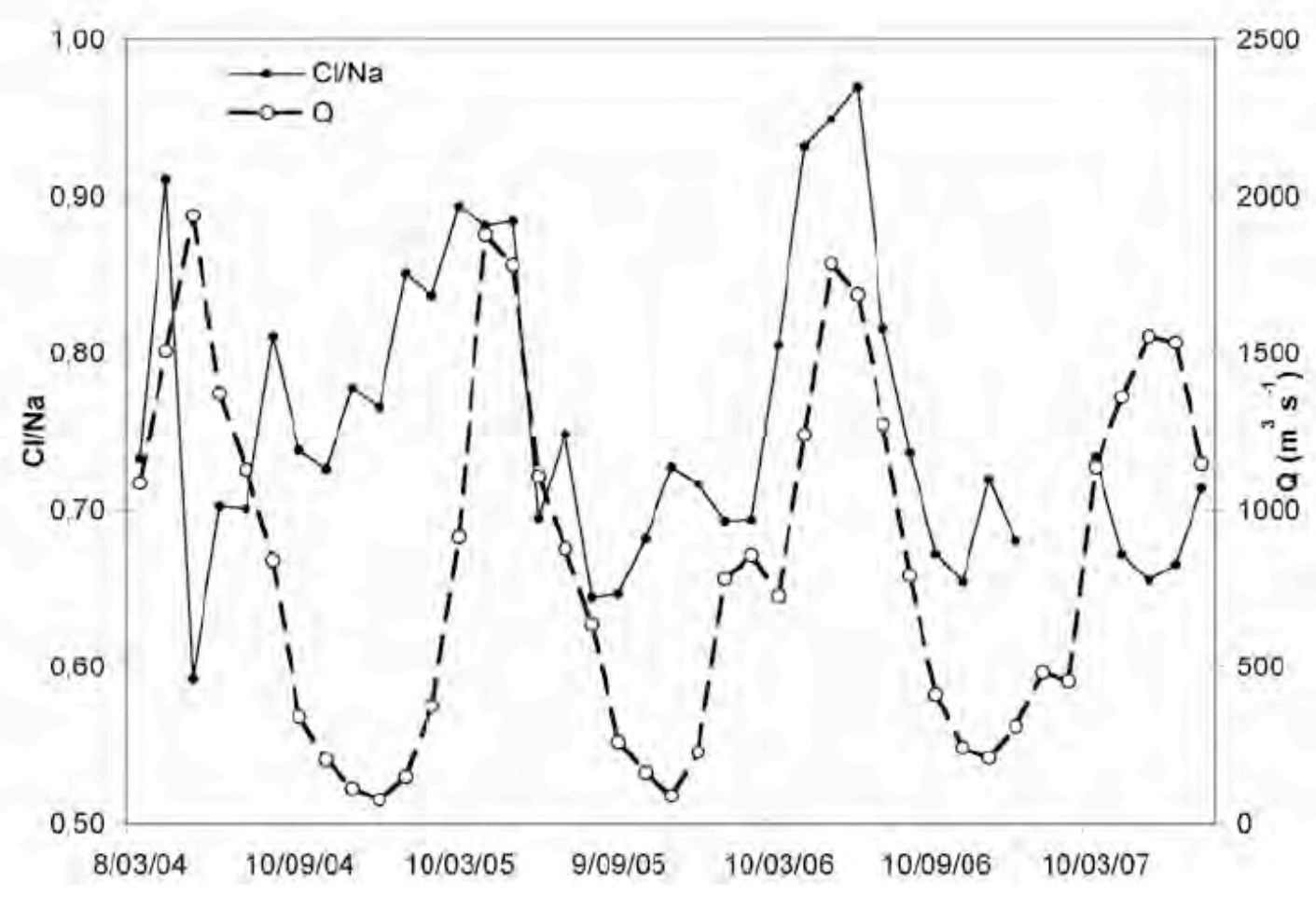

Fig. 10. Cl / Na ratio vs discharge at Saut Maripa 